Karstenia 36: 51-77. 1996

\title{
Tanzanian Myxomycetes: second survey
}

\author{
TARJA UKKOLA, MARJA HÄRKÖNEN AND TIINA SAARIMÄKI
}

UKKOLA, T., HÄRKÖNEN, M. \& SAARIMÄKI, T. 1996: Tanzanian Myxomycetes: second survey. - Karstenia 36:51-77. Helsinki. ISSN 0453-3402.

This work compiles the results obtained by moist chamber cultures of bark material collected in 1988-1989 and field collections made in 1990 and 1991. The collections represent 59 species, 30 of which are new to Tanzania, including Licea tanzanica Ukkola, Härk. \& Gilert which is new to science. The following five are new to Africa: Ceratiomyxa sphaerosperma Boedijn, Cribraria minutissima Schw., Leptoderma iridescens G.Lister, Licea bulbosa Nann.-Brem. \& Y.Yamam. and Physarum perfectum M.E.Peck. Altogether 91 species of Myxomycetes are now reported from Tanzania, the majority of them collected in montane forest belt. Decayed wood, litter, bark of living trees and living herbaceous plants served as substrata. The members of the orders Stemonitales and Physarales were most undemanding in their selection of substrata, and Physarales was the only order that prefered litter to other substratum.

Key words: Africa, Myxomycetes, Tanzania

Tarja Ukkola, Marja Härkönen and Tiina Saarimäki, Department of Ecology and Systematics, P.O. Box 47, FIN-00014 University of Helsinki, Finland.

\section{Contents}

Introduction

Material and methods

Collecting localities

Tanzanian species of Myxomycetes

Order Ceratiomyxales

Order Liceales

Order Echinosteliales

Order Trichiales

Order Stemonitales

Order Physarales

Distribution and habitats

of the Tanzanian Myxomycetes

Substrata

Discussion

Acknowledgements

References

\section{Introduction}

The Myxomycetes of Tanzania were first studied by Eichelbaum (1906), who reported 16 species from the East Usambara Mountains. On the basis of three excursions in Tanzania in 1988-1989, Härkönen and Saarimäki (1991) reported 53 species (collections made in the field), 45 of them new to Tanzania and seven new to Africa. Between 1988 and 1991, altogether six excursions were made to Tanzania each lasting approximately four weeks. This paper reports the results of the three excursions made in 1990-1991 and the results of the moist chamber cultures of bark collections made in 1988-1989. The conclusions about the ecology of the Tanzanian Myxomycetes, and the discussion, are based on the whole material collected in Tanzania between 1988 and 1991. 


\section{Material and methods}

The material was collected by Marja Härkönen and Tiina Saarimäki and identified by Tarja Ukkola. Collections were made during three trips to Tanzania during the rainy season: December 1990, April-May 1991 and November-December 1991. Several vegetation belts were visited, from rain forests to high mountains, miombo woodlands and semideserts. During the three earlier excursions to Tanzania, in 1988 and 1989 (see Härkönen \& Saarimäki 1991), bark from living trees was collected for moist chamber cultures and the results from the cultures are included in this paper. The moist chamber cultures were prepared in Finland by Tiina Saarimäki about five to six weeks after collection. Altogether 223 moist chamber cultures were established. For preparing the moist chamber cultures, see Gilbert \& Martin (1933), Gray \& Alexopoulos (1968), Härkönen (1979) and Härkönen \& Uotila (1983).

The specimens are deposited in the Botanical $\mathrm{Mu}-$ seum, University of Helsinki (H), Finland. Permanent slides of all cited specimens prepared in Hoyer's medium (Martin \& Alexopoulos 1969) are included.

\section{Collecting localities}

The collecting localities are described below and marked by numbers on the map in Fig. 1. Numbers 2-29 refer to places where Myxomycetes and Basidiomycetes were collected during the first three excursions to Tanzania in 1988-1989 (Härkönen \& Saarimäki 1991, Koponen et al. 1990). Only those collecting localities where Myxomycetes were found are listed. Many of these places were revisited in 1990-1991. New collecting sites for Myxomycetes, found in 1990-1991, are numbered 30-39. The capital letter and number, e.g. T2, refer to the geographical subdivision of Tanzania (Polhill 1988). MH refers to collections of Marja Härkönen and TS to collections of Tiina Saarimäki, while mc indicates a collection obtained from a moist chamber culture.

2a. T2, Northern Province, Arusha District. Western foot of Mt. Meru, Olmotonyi, Training forest of the Sokoine University of Agriculture; shady c. 20-year-old stand of Cupressus lusitanica on gently elevating SSW slope, $1830 \mathrm{~m}$. MH $3594 \mathrm{mc}$

2e. T2, Northern Province, Arusha District. Western foot of Mt. Meru, Olmotonyi, Training forest of the Sokoine University of Agriculture, c. 20-year-old stand of Eucalyptys saligna, 2010 m. MH 3595 mc, 3596 A mc, 3596B $\mathrm{mc}$

2h. T2, Northern Province, Arusha District. Western side of Mt. Meru above Laikinoi, ridge between the streams Engare Olmotonyi and Engare Narok, Juniperus procera forest, $2600 \mathrm{~m}$. MH $3597 \mathrm{mc}$

21. T2, Northern Province, Arusha District. Western side of Mt. Meru above Laikinoi, ridge between the Engare Olmotonyi and Engare Narok, upper limit of Hagenia abyssinica forest, with bushes of Stoebe kilimandscharia and Helichrysum spp., 2850-3200 m. MH 3598 mc

3f. T2, Northern Province, Arusha District. Arusha National Park, E slope of Mt. Meru, mossy forest along the path between the View Point and the Njeku campsite, $2600 \mathrm{~m}$. MH $3587 \mathrm{mc}, 3588 \mathrm{mc}$ 3h. T2, Northern Province, Arusha District. Caldera of Mt. Meru; patch of open, temporarily flooded grassland near the Njeku campsite in ericaceous vegetation, $2560 \mathrm{~m}$. MH $3600 \mathrm{mc}$

5a. T2, Northern Province, Moshi District. Moshi International school park, c. $800 \mathrm{~m}$. MH 3575-3577 mc

5b. T2, Northern Province, Moshi District. Moshi. Lutheran hostel, in yard, c. 800 m. MH 3903-3909 mc, 3912-3915 mc

7. T2, Northern Province, Pare District. C. $40 \mathrm{~km}$ from Same along the main road to Mombo; dry deciduous bushland (semidesert), c. $800 \mathrm{~m}$. MH $3601 \mathrm{~A} \mathrm{mc}, 3601 B$ $\mathrm{mc}, 3602 \mathrm{mc}, 3603 \mathrm{mc}, 3604 \mathrm{Amc}, 3604 \mathrm{~B} \mathrm{mc}, 3605 \mathrm{mc}$

10c. T3, Tanga Province, Lushoto District, West Usambara Mts. Mombo, town centre, yard of the restaurant, c. $400 \mathrm{~m}$. $M H 3589 \mathrm{~A} \mathrm{mc}, 3589 B \mathrm{mc}, 3591-3593 \mathrm{mc}$

11n. T3, Tanga Province, Lushoto District, West Usambara Mts. Mazumbai Forest Reserve, lower montane forest, 1400-1600 m. TS 857A, 857B, 927-929, 930A, 930B, 938A, 938B, 939A, 939B, 940-941, MH 3830, 3831A, 3839-3852

11o. T3, Tanga Province, Lushoto District, West Usambara Mts. Mazumbai, nearby the village, 14001500 m. TS 915-917, 918A, 918B, MH 3831B, MH 38323838

12f. T3, Tanga Province, Lushoto District, West Usambara Mts. Lushoto, town centre, yard of the Lawns Hotel. $M H 3572 \mathrm{mc}, 3573 \mathrm{~A} \mathrm{mc}, 3573 \mathrm{~B} \mathrm{mc}$

18a. T3, Tanga Province, Lushoto District, East Usambara Mts. Amani Medical Research Centre, 850$950 \mathrm{~m}$. MH $3567 \mathrm{mc}$

18b. T3, Tanga Province, Lushoto District, East Usambara Mts. Amani Forest Reserve, tropical submontane rain forest, c. $900 \mathrm{~m}$. MH 3861

18g. T3, Tanga Province, Lushoto District, East Usambara Mts. Amani, near the Rest House, c. $900 \mathrm{~m}$. MH 3860

19. T3, Tanga Province, Tanga District. Baobab Beach Hotel, $7 \mathrm{~km}$ South of Tanga near Mwambani village, $5 \mathrm{~m}$. MH $3569 \mathrm{mc}, 3570 \mathrm{~A} \mathrm{mc}, 3570 B \mathrm{mc}$

26a. T6, Eastern Province, Morogoro District. Morogoro, Sokoine University of Agriculture, the campus area plantations, c. $500 \mathrm{~m}$. MH $3560-3561 \mathrm{mc}, M H$ $3568 \mathrm{~A} \mathrm{mc}, 3568 \mathrm{~B} \mathrm{mc}$, $\mathrm{MH} 3586 \mathrm{Amc}, 3586 \mathrm{~B} \mathrm{mc}$

26c. T6, Eastern Province, Morogoro District. Hillside of the Uluguru Mts. in vicinity of the town of Morogoro; thinned and partly cultivated miombo woodland with Brachystegia microphylla and B. boehmii. $M H$ 3562-3564 mc

27e. T6, Eastern Province, Morogoro District. E slope of N Uluguru Mts., Kimboza Forest Reserve, lowland rain forest, 200-440 m. TS 792, MH 3813-3818, 38223825

29a. T3, Tanga Province, Pare District, South Pare Mts., Mbaga Manka village, yard of the Lutheran Missionary House, alt. c. 1500 m. $M H 3772,3775 A$, 3775B, 3776

29b. T3, Tanga Province, Pare District, South Pare Mts., Mbaga Manka village, up from the Lutheran Missionary House, 1500 m. MH 3773

30a. T3, Tanga Province, Pare District, South Pare Mts., Mpepera village, in Acacia and Eucalyptus forest, c. $1600 \mathrm{~m}$. MH 3777, 3778A, 3778B, 3781A, 3781B, 3781C, $3783,3786-3787$ 


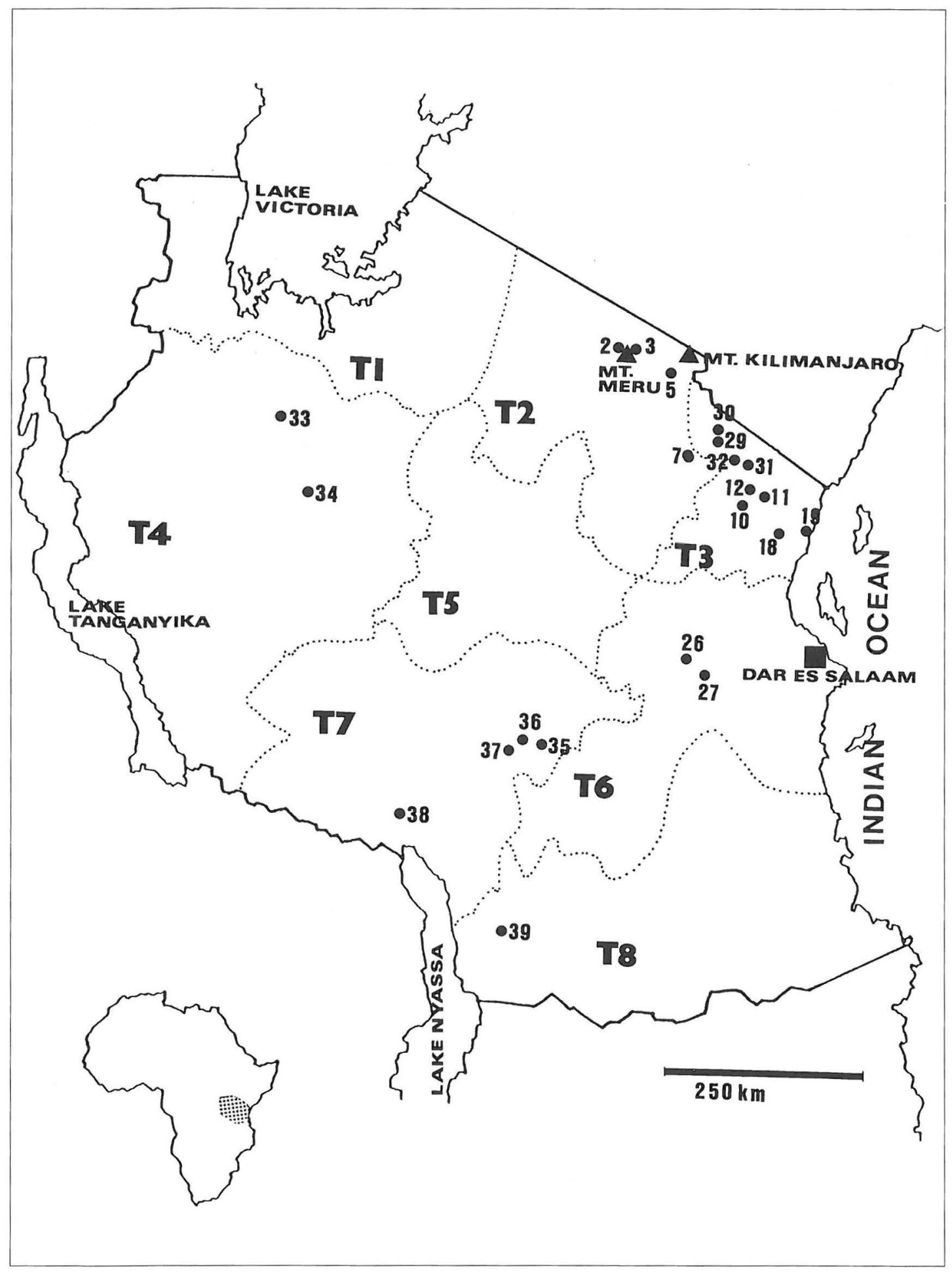

Fig. 1. Tanzania. Collecting sites of Myxomycetes. The numbers are explained in the list of collecting localities, page 4. Map compiled from Polhill (1988), Härkönen et al. (1993) and two road maps. 
30b. T3, Tanga Province, Pare District, South Pare Mts. Mpepera village, natural montane forest, c. $1600 \mathrm{~m}$. MH 3784-3785

31. T3, Tanga Province, Pare District, E slope of South Pare Mts. Gonja, Mjema village, in coffee and banana plantation, c. 1400 m. MH 3862

32. T3, Tanga Province, Pare District, E slope of South Pare Mts. Gonja, Bombo village, near Gonja Lutheran hospital, c. $1350 \mathrm{~m}$. $M H$ 3863-3866

33. T4, Western Province, Kahama District, c. 40 km SW of Kahama, Mpunze Forest Reserve, in woodland (Brachystegia, Terminalia, Combretum, Rothmannia, Hyphaene), c. $1150 \mathrm{~m}$. MH 3867, 3868

34. T4, Western Province, Tabora District, c. $20 \mathrm{~km}$ W of Tabora, Lulanguru village, in woodland (Brachystegia, Terminalia, Combretum, Dichrostachys, Annona, Vitex, Markhamia), c. 1100 m. MH 3869

35. T7, Southern Highlands Province, Iringa District, Mufindi, Lulando village. Lulando Forest Reserve, lower montane forest, c. $2000 \mathrm{~m}$. TS 634-635, MH 3788-3798, $3799 A, 3799 B$

36. T7, Southern Highlands Province, Iringa District, Mufindi, Kibao. Acacia mearnsii and Eucalyptus plantations near Sailing Club, c. $1900 \mathrm{~m}$. TS 643-646, MH 3804-3808, 3879

37. T7, Southern Highlands Province, Iringa District, Mufindi, Fishing Club by Kilima Tea Estate, degenerated forest plantation (Eucalyptus and Acacia), c. $1900 \mathrm{~m}$. MH 3810-3811

38. T7, Southern Highlands Province, Rungwe District, Mwakaleli, Training Centre, Old Missionary House, in yard, c. $1750 \mathrm{~m} . \mathrm{MH} 3820-3821$

39. T8, Southern Province, Songea District, $45 \mathrm{~km} \mathrm{~W}$ of Songea, Lipokela, in degraded miombo woodland dominated by Uapaca, $1100 \mathrm{~m}$. TS 613

In addition to the above localities, two specimens were collected in Malawi:

40. Malawi, Zomba District, Zomba, near Government Hostel, 850 m. MH 3828

41. Malawi, Zomba District, c. $20 \mathrm{~km}$ North of Zomba, Makawara village, Uapaca-Brachystegia woodland, $850 \mathrm{~m}$. MH 3829

\section{Tanzanian species of Myxomycetes}

The species of Myxomycetes collected in Tanzania in 1988-1989 have been briefly described by Härkönen and Saarimäki (1991). The present paper lists all the specimens found in Tanzania after that study. Species that are new to Tanzania are described on the basis of the Tanzanian material. The collecting localities are not listed in the descriptions, but indicated by numbers, or numbers and letters, in boldface, as explained above and shown in Fig. 1.

In total 162 specimens were studied. Of these, 111 were collected in the field in 19901991 and 51 were harvested from moist chamber cultures prepared from the bark collections made in 1988-1989. The collections comprised 59 species, one of them being new to science and five new to Africa. The field collections included 38 species, and 25 species were obtained from the moist chamber cultures (four species the same as in the field). All specimens are deposited at the Botanical Museum of the University of Helsinki (H).

The nomenclature follows Martin \& Alexopoulos (1969) with some exceptions. Species were identified and their distribution checked with the aid of the literature listed in the references, mainly by Lister (1925), Martin \& Alexopoulos (1969), Nannenga-Bremekamp (1991), Farr (1976, 1981), Emoto (1977), Mitchell (1980) and Neubert et al. (1993). In addition to the above mentioned references the distribution in Africa was checked from the following publications: Almeida (1973, 1974a, 1974b), Bañares Baudet \& Beltrán Tejera (1987), Bañares Baudet et al. (1986, 1987), Beltrán Tejera (1975), Beltrán Tejera et al. (1987,1989), Bresadola \& Saccardo (1899), Buyck \& Rammeloo (1983), Champion \& Beltrán Tejera (1980), Dixon (1959), Doidge (1950), Duthie (1917a, 1917b), Eichelbaum (1906), Ejale \& Gill (1991, 1992, 1995), Farquharson \& Lister (1916), Farr (1959), Faurel et al. (1965), Faurel \& Schotter (1965), Gill \& Onyibe (1986), Gràcia (1986), González Luis \& Beltrán Tejera (1987), Härkönen (1981), Härkönen \& Saarimäki (1991), Ing (1964, 1967), Ing \& McHugh (1968), Maire et al. (1926), Malençon \& Bertault (1967), Mitchell \& Kylin (1984), Patouillard (1897, 1928), Rammeloo (1973a, 1973b, 1981a, 1981b), Rammeloo \& Mitchell (1994) and Wildpret \& Beltrán (1974).

\section{Order Ceratiomyxales}

A total of 37 specimens of the order Ceratiomyxales were collected from Tanzania. The following specimens are new species for Tanzania and additions to the already reported ones (see Härkönen \& Saarimäki 1991).

\section{Ceratiomyxa fruticulosa (O.F.Müll.) Macbr.}

11n:3851 MH, $3852 M H, 927 T S$, 11o:3834 MH, 917 TS, 18g:3860 MH, 27e:3817 MH, 3822 $\mathrm{MH}, 3824 \mathrm{MH}, 792 \mathrm{TS}, 35: 3796 \mathrm{MH}, 37: 3810$ 
MH. Seven specimens from montane forest, one from submontane rain forest and four from lowland rain forest; eleven specimens on decaying wood, one on plant litter. Cosmopolitan.

Three specimens (MH 3851, 3852, TS 917) represent var. porioides (Alb. \& Schw.) Lister (Lister 1925). Fructifications are honeycomb-like. Emoto (1977) considered this a distinct species, but we consider it a variety of $C$. fructiculosa following Neubert et al. (1993).

\section{Ceratiomyxa sphaerosperma Boedijn}

11n:928 TS. One specimen from montane forest; on decayed wood. Relatively common in the tropics and subtropics. No earlier reports from Africa.

Fructifications, $1-2 \mathrm{~mm}$ in total height, scattered or loosely gregarious, composed of a fairly short, brownish stalk, darker at the base, bearing a cluster of thin, branched or unbranched arms. Spores hyaline by transmitted light, globose or ellipsoid, nearly smooth, by oil-immersion some scattered warts, with granular contents, 9- $\underline{9.9}-11 \mu \mathrm{m}$ or $13.5-\underline{13.8}-16 \times 6.5-$ $\underline{7.6}-8 \mu \mathrm{m}$.

In most references the spores are described as subspherical or spherical. In this specimen there were also elliptical spores. The species is fairly common in the tropics and subtropics (Martin \& Alexopoulos 1969, Neubert et al. 1993, Stephenson \& Stempen 1994).

\section{Order Liceales}

We collected 54 specimens of the order Liceales in Tanzania in 1988-1991. These specimens belong to the genera Licea (18), Tubifera (3), Lycogala (14), Dictydiaethalium (1) and Cribraria (18). New specimens, representing species new to Tanzania, are described below.

\section{Licea biforis Morgan}

12f:3573B $M H$ mc. One specimen from the Lushoto town centre, alt. c. $850 \mathrm{~m}$; on Juniperus procera. Widely distributed in the world. In Africa reported from northern and western parts and from the Canary Islands; no earlier reports from eastern Africa.
Sporangia or short plasmodiocarps in small groups, sessile, somewhat compressed laterally, fusiform, occasionally branched, dark yellowish brown to dark brown except the pale yellow line of dehiscence; 300-800 $\mu \mathrm{m}$ long. Peridium thin, shiny, dark yellowish brown, almost colourless in transmitted light, minutely papillose inside; covered - except the dehiscence line - with a gelatinous layer with inclusions. Spores yellow in mass, pale yellow in transmitted light, globose to subglobose, thin walled, very minutely but densely warted, 1214.7-17 $\mu \mathrm{m}$ in diameter.

The specimen examined is somewhat immature, the spore diameter varied much more than normally owing to some extra large spores. According to Martin \& Alexopoulos (1969) the spore diameter is $9-12(-15) \mu \mathrm{m}$, while according to Emoto (1977) it is $12-19 \mu \mathrm{m}$.

The specimen grew mixed with Licea parasitica.

\section{Licea bulbosa Nann.-Bremek. \&}

Y.Yamam. - Figs. 2-4

5a:3575 MH mc, 3577 MH mc, 26a:3568A MH mc, $3586 \mathrm{~A} M H \mathrm{mc}, 26 \mathrm{c}: 3562 \mathrm{MH} \mathbf{~ m c}, 3563$ $M H$ mc. Two specimens from lowland, two from submontane belt, all on Jacaranda mimosifolia; two specimens from miombo on Brachystegia microphylla. Reported from Japan. New to Africa.

Sporangia scattered or gregarious, stipitate, globose to subglobose, somewhat shiny brown to darkish brown, with a broad, convex lid above, often darker at the base; total height 150-450 $\mu \mathrm{m}, 70-100(-150) \mu \mathrm{m}$ in diameter. Peridium thin, pale olivaceous by transmitted light, weakly warted, warts often joined into ridges, partially smooth; covered with a gelatinous layer with inclusions; dehiscence circumscissile, leaving a moderately deep cup and a broad, convex, free lid. Stipe more or less thick, sometimes slightly tapering, dark brown to black, half to nearly two thirds the total height, sometimes shorter, filled with refuse matter. Spores ochraceous with olivaceous tint in mass, very pale olivaceous or nearly colourless by transmitted light, globose, smooth in light microscope, punctate in SEM, thin-walled with a paler area, 7.5- $\underline{8.5}-11.5 \mu \mathrm{m}$ in diameter. 

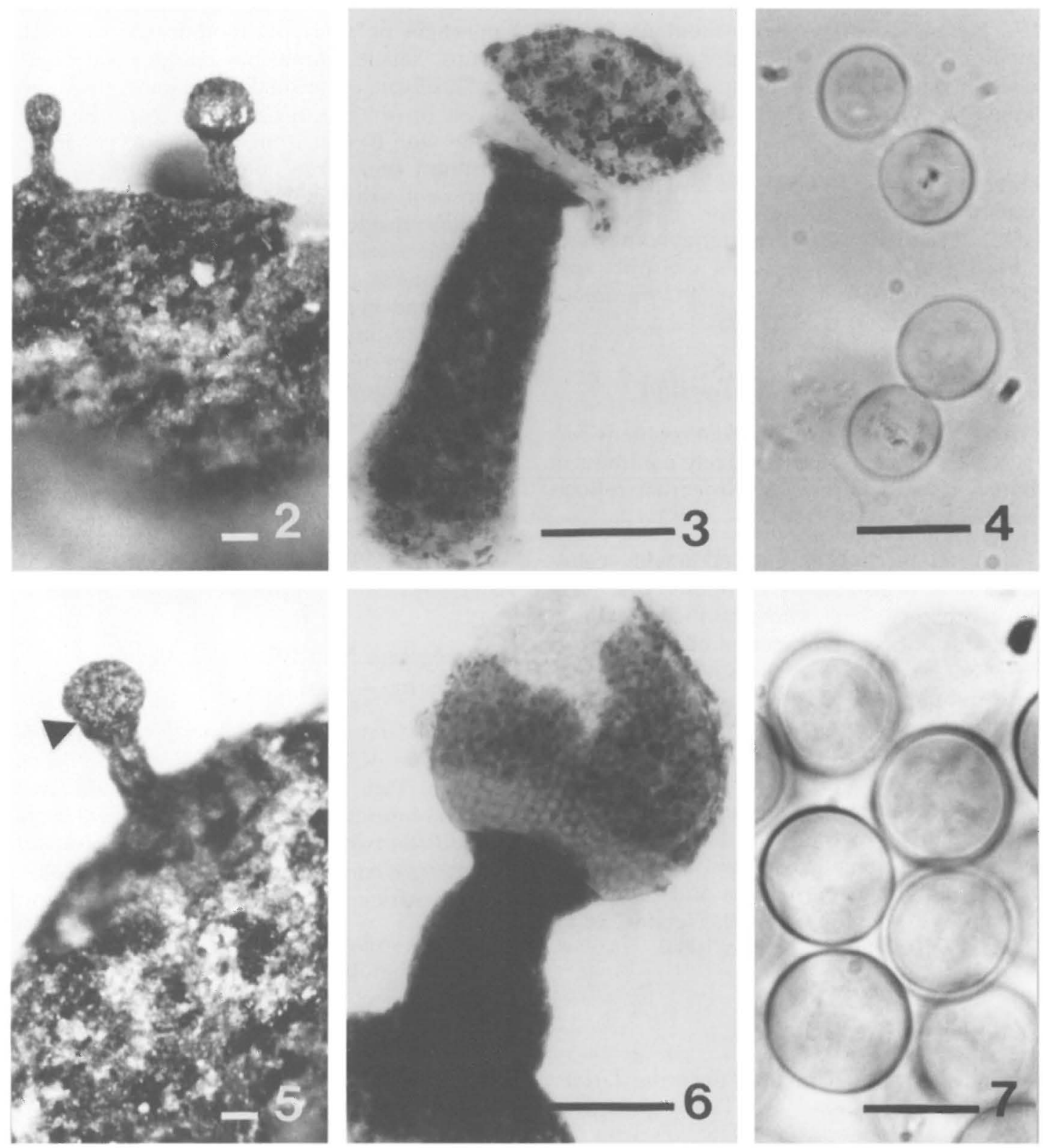

Figs. 2-7. Licea bulbosa and L. tanzanica. - 2-4. L. bulbosa (Härkönen 3577, 3586A). 2: a dissecting microscope photo. Bar $=75 \mu \mathrm{m}$. 3: a compound microscope photo, the dehiscence of the sporangium is circumscissile. Bar $=100 \mu \mathrm{m} .4$ : some spores of L. bulbosa. Bar $=10 \mu \mathrm{m} .-5-7$. L. tanzanica (holotype). 5: a dissecting microscope photo. Bar $=75 \mu \mathrm{m}$. Note the weak line of a circumscissile dehiscence (arrow). 6: a compound microscope photo, the dehiscence of the peridium in this sporangium is irregular. Bar $=100 \mu \mathrm{m}$. 7: some spores of $L$. tanzanica. Bar $=10 \mu \mathrm{m}$.

One specimen ( $M H 3568 A$ ) grew mixed with Calomyxa metallica and one specimen ( $M H$ 3586A) with Arcyria pomiformis.

The species has recently been described (Nannenga-Bremekamp \& Yamamoto 1987) on the basis of a single specimen developed in a moist chamber on the bark of a living tree from Japan. We have examined a slide of the type specimen, kindly sent by late Mrs. Nannenga-Bremekamp, and our material matches it perfectly; even the peridium which was described as smooth seems to be weakly 
warted in some places. The Tanzanian material, which comprises six specimens, shows the sizes of the sporangia and the spores to vary more widely than announced in the description of the species. According to NannengaBremekamp and Yamamoto (1987), the sporangia are $150-200 \mu \mathrm{m}$ in total height and the spores $10-11 \mu \mathrm{m}$ in diameter.

\section{Licea parasitica (Zukal) Martin}

7:3602 MH mc, 12f:3573A MH mc. One specimen from the town centre (Lushoto, submontane belt), on Juniperus procera; the other from semidesert Commiphora bush (alt. c. 850 $\mathrm{m})$, on Delonix elata. Common all over the world. Earlier reports from Africa from Tunisia (Mitchell \& Kylin 1984) and the Canary Islands (Champion \& Beltrán Tejera 1980).

Sporangia scattered or in groups, sessile, subglobose, sometimes somewhat prolate, dark brown to black, occasionally shiny, 50-300 $\mathrm{mm}$ in diameter; opening by a lid, when this is lacking by apical, irregular dehiscence. Peridium covered with a gelatinous layer with refuse matter; peridial layer thin, pale brownish, minutely papillose. Spores darkish brown to brown in mass, olive-brown in transmitted light, globose, smooth, thick-walled with a large, paler, thinner area, (10-)10.5-12.1-13 $\mu \mathrm{m}$ in diameter. The lid was not conspicuous in these specimens, but according to Martin \& Alexopoulos (1969) it sometimes seems to be absent because in drying it becomes "a delicate, easily detached film". Licea denudescens is close to L. parasitica but has no preformed lid, the inner peridium is strongly papillate and the spores are smaller, 8.5- $\underline{9.5}-11.5 \mu \mathrm{m}$ (Keller \& Brooks 1977).

One of the specimens (on Juniperus procera) grew mixed with Licea biforis.

\section{Licea cf. pedicellata (H. C. Gilbert) H. C. Gilbert}

2a:3594 MH mc. One specimen from montane forest. On Cupressus lusitanica. Reported from Africa from Tunisia (Mitchell \& Kylin 1984).

Sporangia scattered, stipitate, globose to subglobose, minute, total height $0.4-0.5 \mathrm{~mm}$, $0.2-0.3 \mathrm{~mm}$ in diameter; dark brown to blackish. Peridium covered with gelatinous layer with inclusions (yellowish olive brown by transmitted light); peridial layer thin, smooth. Stalk thick, dark brown to black, furrowed, filled with refuse matter. Spores brown in mass, olivaceous brown by transmitted light, globose to subglobose, thick-walled with a wide paler area, smooth, 8-9.2-10 ìm in diameter.

This scanty specimen approaches $L$. pedicella$t a$, but the spores are smaller and totally smooth.

\section{Licea tanzanica Ukkola, Härk. \& Gilert sp. nov. - Figs. 5-10}

5a:3576 MH mc, 5b:3905 MH mc, $3915 \mathrm{MH}$ mc, 10c:3589B MH mc, $3591 \mathrm{MH}$ mc, 3592 MH mc, 3593 MH mc, 18a:3567 MH mc. Four specimens from lowland on Araucaria cunninghamii or Azadirachta indica; four specimens from submontane belt on Jacaranda mimosifolia, $A$. cunninghamii or Mangifera indica.

Sporangia dispersa vel gregaria, stipitata, globosa vel subglobosa, brunnea vel saturate brunnea, ad altitudinem totam 150-400 $\mathrm{mm}$ alta, 90-150(-200) $\mu \mathrm{m}$ lata. Peridium tenue, pallidum, verrucosum, substantia granulosa tectum, dehiscentia circumscissili vel irregulari. Stipes altitudine tota sporangii dimidia - quarta parte brevior, crassus, sulcatus, interdum brevissimus et basi latior, brunneus vel saturate brunneus. Sporae per saturam aliquantum pallide brunneae, lucem orientem versus visae pallide brunneolae, globosae, laeves, parietibus non crassissimis, area lata pallidiore, 12-13.0$15 \mu \mathrm{m}$ diametro.

Holotype: Tanzania. Tanga Prov.: Lushoto Distr., W Usambara Mts., on Azadirachta indica in moist chamber culture, 12.XII.1988 Härkönen $3693(\mathrm{H})$.

Sporangia scattered or loosely gregarious, stipitate, sometimes nearly sessile with a restricted base, globose or subglobose to slightly clavate or angular, somewhat shiny, brown to dark brown, erect; total height 150-400 $\mathrm{\mu m}$, $90-150(-200) \mu \mathrm{m}$ in diameter. Peridium thin, pale, slightly olivaceous by transmitted light, warted, warts sometimes joined into short ridges; covered with granular matter; dehiscence circumscissile or irregular. Stalk one half to nearly two thirds of the total height, thick, erect, furrowed, occasionally tapering upwards, sometimes very short and wider at the base, concolourous with the sporangium or darker. 

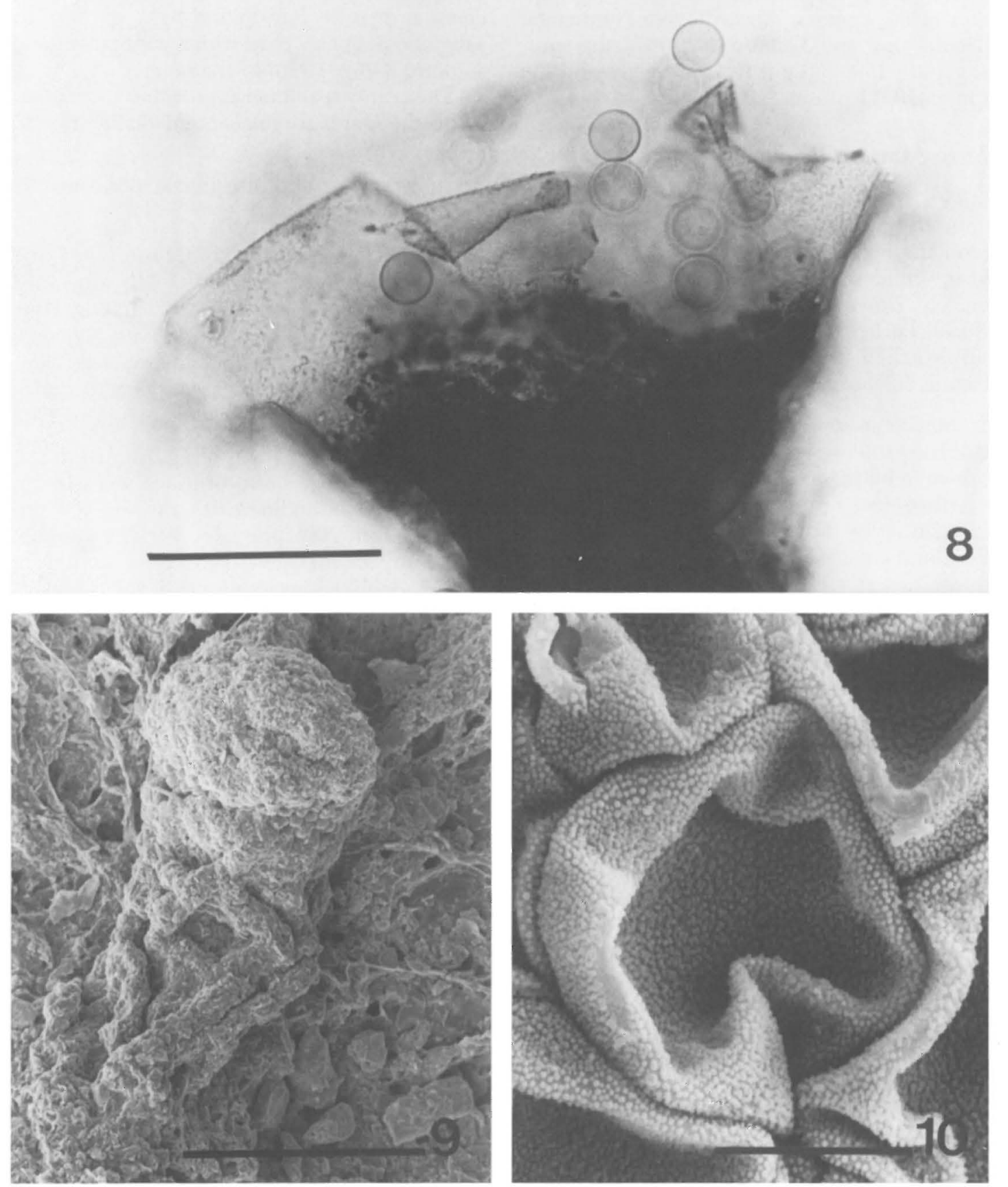

Figs. 8-10. Licea tanzanica (holotype). - 8: part of warted peridium and some spores. Bar = 50 $\mu$ m. $-9-10$ : SEM micrographs. 9: one sporangium. Bar $=100 \mu \mathrm{m}$. 10: some collapsed punctate spores. Bar $=5 \mu \mathrm{m}$. 
Spores palish brown in mass, pale brownish with olivaceous tint by transmitted light, globose, smooth in light microscope even in high magnification, punctate in SEM, not very thickwalled, with a wide, paler area, often with pale inclusions, $12-\underline{13.0}-15 \mu \mathrm{m}$ in diameter.

The distinguishing characteristics of Licea tanzanica are the brown stipitate, erect, globose or subglobose sporangia dehiscing in circumscissile fashion or irregularly (Figs. 5-6, 8-9) and the relatively large spores with not very thick walls (Figs. 7, 10).

Licea tanzanica resembles in habitus L. bulbosa Nann-Bremek. \& Y.Yamam., L. capitata Ing \& McHugh, L. capitatoides Nann.-Bremek. \& Y. Yamam., L. pedicellata (H.C. Gilbert) H.C. Gilbert, L. rugosa Nann-Bremek. \& Y.Yamam. and L. scyphoides Brooks \& Keller.

Licea bulbosa differs from L. tanzanica in always exhibiting circumscissile dehiscence, leaving a cup and a lid, and also in having smaller, paler, thinner-walled spores. $L$. capitata is ochraceous in colour, opens by a vertical split and the spores are smaller, very pale yellow by transmitted light (Ing 1982). L. capitatoides is smaller, dark grey in colour and has small (7$9 \mu \mathrm{m})$, brown spores (Nannenga-Bremekamp \& Yamamoto 1990). L. tanzanica differs from $L$. pedicellatain its thinner walled and paler spores, which look totally smooth under the light microscope. L. rugosa has spores, which are thick-walled and dark brown by transmitted light (Nannenga-Bremekamp \& Yamamoto 1987). L. scyphoides has circumscissile dehiscence and minutely roughened spores (Keller \& Brooks 1977).

Dr. Elisabeth Gilert (Gothenburg) examined specimens of $L$. tanzanica (and $L$. bulbosa) and took SEM micrographs, which revealed that the spores are not totally smooth but minutely punctate. We have studied slides of type specimens of Licea bulbosa and L. rugosa kindly sent by late Mrs. Nannenga-Bremekamp, and Dr. Keller has seen some of our material and compared it with L. scyphoides. We have also examined the type specimen of Licea pedicellata, sent by NFC.

All our specimens of Licea tanzanica emerged on bark collected from trees growing in town areas in lowland or submontane belt (alt. under $1000 \mathrm{~m}$ ). No specimens of the genus Licea emerged on the numerous bark collections from high elevation (alt. above $2000 \mathrm{~m}$ ).
One specimen (3589A) grew mixed with Badhamiopsis ainoae.

Additional material examined. Tanzania. Northern Prov: Moshi Distr., Moshi International school park (03 37 $\mathrm{AD})$, in moist chamber culture on Jacaranda mimosifolia, $800 \mathrm{~m}, 23 . \mathrm{V} .1988$ Härkönen 3576. Lutheran hostel, in moist chamber culture on Mangifera indica, $800 \mathrm{~m}$, XII.1989 Härkönen 3905. In moist chamber culture on Araucaria cunninghamii, 800 m, XII.1989 Härkönen 3915. Tanga Prov.: Lushoto Distr., E Usambara Mts., Amani Medical Research Centre (05 38 BA), in moist chamber culture on Araucaria cunninghamii, 850-950 m, 08.XII.1988 Härkönen 3567. W Usambara Mts., Mombo, town centre (04 $38 \mathrm{CD}$ ), in moist chamber culture on Azadirachta indica, 400 m, 12.XII.1988 Härkönen 3591, 3592. In moist chamber culture on Araucaria cunninghamii, $400 \mathrm{~m}$, 12.XII.1988 Härkönen 3589B.

\section{Lycogala epidendrum (L.) Fr.}

27e:3825 MH, 36:3806 MH, 643 TS. Two specimens from montane forest, one from lowland rain forest; on decaying wood. Cosmopolitan.

\section{Dictydiaethalium plumbeum (Schum.) Rostaf.}

11n:3830 $\mathrm{MH}$. One specimen from lower montane forest; on decaying Parinari. Cosmopolitan. Reported from many parts of Africa.

Pseudoaethalium depressed, composed of numerous closely connected sporangia, about 13 x $30 \mathrm{~mm}$ in diameter and $0.5-1.0 \mathrm{~mm}$ thick, light brown. Cortex of polyhedral plates, composed of the thickened caps of the sporangia. Hypothallus white, protruding outside the aethalium. Pseudocapillitium composed of thickened strands, $4-5 \mu \mathrm{m}$ in diameter, which are remains of the vertical sporangial walls, running from the corners of the platelets to the base. One side of the strands is often thickened and roughened, bearing thin, fringy threads. Spores brown-yellow in mass, almost colourless in transmitted light, globose, distinctly spinulose, $8.5-\underline{9.1}-10 \mu \mathrm{m}$ in diameter.

\section{Cribraria minutissima Schw.}

2e:3595 $\mathrm{MH}$ mc. One specimen from montane forest, on bark of Eucalyptus saligna. Reported from North and South America, West-Indies, Europe and Asia. New to Africa.

Sporangia loosely gregarious, stipitate, erect or suberect, subglobose to oblong, orange- 
brown to brownish-red; $0.1-0.3 \mathrm{~mm}$ in diameter, $0.35-1(-1.2) \mathrm{mm}$ tall. Peridium persisting as a deep, distinct cup, about one third to one half of the sporangia bearing pale granules; clearly delimited from the peridial net; the rim of the cup smooth. Peridial net forming angular meshes, threads flattened, lacking dictydine granules, slightly expanded at the nodes; nodes not thickened. Stipe slender, long, red-brown, darker at the base (refuse matter), tapering upwards. Spores orange-brown in mass, pale yellow in transmitted light, globose, covered with fine warts, $8-\underline{8.2}-9 \mu \mathrm{m}$ in diameter.

According to many investigators the sporangia of Cribraria minutissima may or may not possess a peridial cup. According to Nannenga-Bremekamp \& Yamamoto (1983), C. minutissima should be restricted to the specimens with a distinct cup. The cupless form was described as C. confusa Nann.-Bremek. \& Y. Yamam.. In ultrastructural studies Keller et al. (1988) have shown that two species exist even if they sometimes grow mixed. C. confusa differs from

C. minutissima not only in the lack of calyculus but in the peridial net and the colour and ornamentation of the spores. Härkönen (1981) recorded from Gambia seven specimens with the name $C$. minutissima. All of them are without any kind of cup, and belong to the separate species $C$. confusa. Thus the present specimen is the first record of $C$. minutissima in Africa.

According to Keller et al. (1988), many species of Cribraria occur on ground sites, e.g. on decaying logs, and only $C$. minutissima, $C$. confusa and $C$. violacea have been found with regularity on the bark of living trees.

\section{Order Echinosteliales}

The two specimens listed below are the only representatives of the order Echinosteliales collected in Tanzania in 1988-1991.

\section{Echinostelium minutum de Bary}

2e:3596B $M H$ mc, 26a:3561 $M H$ mc. One specimen from montane forest on bark of $E u$ calyptus saligna, one from lowland rain forest on bark of Tectona grandis. Cosmopolitan. Re- ported from North and West Africa and from the Canary Islands, no previous records from eastern Africa.

Sporangia gregarious or scattered, stipitate, 40 $70 \mu \mathrm{m}$ in diameter, 300-500 $\mathrm{m}$ tall, globose, white to beige. Peridium fugacious, leaving a small collar at the base. Stipe long, several times longer than the head of the sporangium, hair-like, tapering upwards, containing granular particles. Columella short, cylindrical. Capillitium scanty, composed of a few colourless dichotomously branched threads with horn-like endings, sometimes forming a few meshes. Spores white in mass, colourless in transmitted light, globose, smooth, 7- $\underline{7.5}-8(-9)$ $\mu \mathrm{m}$ in diameter. tis.

One specimen grew mixed with Trichia botry-

\section{Order Trichiales}

A total of 133 specimens of order Trichiales were collected in Tanzania in 1988-1991. These specimens belong to the following genera: Calomyxa (1), Perichaena (8), Arcyria (83), Trichia (2), Hemitrichia (35) and Metatrichia (4).

\section{Calomyxa metallica (Berk.) Nieuwl.}

26a:3568B $M H$ mc. One specimen from lowland; on bark of Jacaranda mimosifolia. Reported from many parts of the world. Earlier reports from Africa are from the northern and central parts and from the Canary Islands.

Sporangium sessile, subglobose, umbilicate; iridescent yellow; $0.7 \mathrm{~mm}$ in diameter. Peridium membranous, translucent, shiny, partially with fine warts. Capillitial threads tangled with loops, elastic, yellow-brown, single or scarcely branched; treads yellow in transmitted light, marked with spirally arranged fine warts, 1$1.5 \mu \mathrm{m}$ in diameter. Spores ochraceous in mass, pale yellow in transmitted light, globose, distinctly spinulose, $9,5-\underline{10.3}-11 \mu \mathrm{m}$ in diameter.

There was only one sporangium of Calomyxa metallica in this specimen and it grew mixed with Licea bulbosa.

Calomyxa metallica is not rare in moist chamber cultures, it has been reported for example, from southern Finland (Härkönen 1979) and the Hawaiian Islands (Eliasson 1991). 


\section{Perichaena chrysosperma (Currey) A.Lister}

5b:3908 $M H$ mc. One specimen from submontane rain forest; on Juniperus procera. Cosmopolitan. Reported from many parts of Africa.

Sporangia gregarious, sessile, subglobose, ringshaped or elongated to short plasmodiocarps; $0.2-0.5 \mathrm{~mm}$ wide and up to $1 \mathrm{~mm}$ long, brown, dark-brown or reddish brown. Peridium double, the outer layer with granules, inner thin, translucent; dehiscence irregular. Capillitial threads yellow, elastic, scarcely branched, filled with granules, 2-3(-3.5) $\mu \mathrm{m}$ in diameter; ornamentation long spines, up to $6 \mu \mathrm{m}$; ends clavate. Spores bright yellow in mass, yellow in transmitted light, globose to slightly subglobose, covered with regular fine spines, 9- $\underline{9.5-}$ $11 \mu \mathrm{m}$ in diameter.

Fructifications vary widely in shape. The specimen grew mixed with Perichaena depressa and Physarum diderma.

\section{Perichaena corticalis (Batsch) Rostaf. var. corticalis}

5b:3904 MH mc, 12f:3572 MH mc. One specimen from the town centre (Lusotho, alt. ca. $850 \mathrm{~m}$ ) on bark of Juniperus procera, one from submontane rain forest on bark of $J$. procera. Cosmopolitan. Reported from several parts of Africa, no previous records from eastern Africa.

Sporangia solitary, sessile, globose or subglobose (somewhat depressed), 0.25-0.80 $\mathrm{mm}$ in diameter; brown to greyish brown, an undulating dehiscence line at the edge. Peridium thick, double, the outer layer with granular material, the inner thin, membranous; opening with an uneven, broad lid. Hypothallus inconspicuous. Capillitium scanty, composed of yellow, thin threads; nearly smooth or covered with fine warts or short spines, 1.5-2.5 $\mu \mathrm{m}$ in diameter. Spores in mass yellow-brown to bright yellow, yellow in transmitted light, globose, minutely warted, 9-10.8-11 $\mu \mathrm{m}$ in diameter.

Both specimens were scanty and exist only as permanent slides.

According to Nannenga-Bremekamp (1991) this species is not very common in moist chambers (when obtained, often small and solitary); it usually grows on bark of dead trees. From moist chambers it has been obtained for example, from Turkey (Härkönen \& Uotila 1983) and Hawaii (Eliasson 1991); Mitchell (1980) also mentions it from bark of living trees. According to Neubert et al. (1993), P. corticalis usually grows on deciduous trees.

\section{Perichaena corticalis var. liceoides (Rostaf.)} A.Lister

3h:3600 MH mc, 3f:3587 MH mc, $3588 M H$ mc. Three specimens from Ericaceous belt; on bark of deciduous trees. An earlier report from Africa is from Morocco (Malençon \& Bertault 1967).

Sporangia sessile, subglobose or short plamodiocarps, tiny, 0.3-0.4 $\mathrm{mm}$ in diameter, light brown to yellowish brown, sometimes shiny. Peridium fragile, covered with a layer with inclusions; dehiscence irregular. Hypothallus thin, membranous, inconspicuous. Capillitium undeveloped. Spores yellowish brown in mass, yellow in transmitted light, globose to slightly angular, spiny, sometimes with groups of more distinct spines, 12.5-14.3$15.5 \mu \mathrm{m}$ in diameter.

The variety was described as a species, Perichaena liceoides, by Rostafi ski, whose description was based on material collected by Cienkowski (Gilert 1990). Lister (1925) and Hagelstein (1944) considered P. liceoides to be a variety of $P$. corticalis. Gilert (1990) studied the type collection and considered it to be a minute form of $P$. corticalis. No capillitial threads were found in the material collected in Tanzania. The spore size is larger than given in Rostafi ski's description $(9.2-10 \mu \mathrm{m})$. Whereas Rostafi ski described the spores as smooth, our material is comparable to Gilert's (1990) in being covered with prominent spines. The Tanzanian specimens were corticolous, but the type collection of $P$. liceoides grew on leaves (Gilert 1990). Two collections cited by Lister as $P$. corticalis var. liceoides were found on the dung of fallow deer and on hedge clippings (Lister 1925).

\section{Perichaena depressa Libert}

5b:3906 MH mc, 3909 MH mc. Two specimens from submontane rain forest. On 
Juniperus procera. Cosmopolitan. Reported from almost every part of Africa.

Sporangia crowded, depressed, discoid, polyhedral due to mutual contact, red-brown to dark-brown, $0.1-1.5 \mathrm{~mm}$ in diameter. Peridium thick, double, outer layer with granules closely appressed to the thin inner layer. Dehiscence by a lid formed from the upper part of the peridium, the basal part a shallow cup. Capillitium of thin, yellow, scarcely branched threads, covered with warts and spines, 1.5-2 $\mu \mathrm{m}$ in diameter. Spores bright yellow in mass, yellow in transmitted light, globose, regularly minutely warted, (8-)9- $\underline{9.5}-10.5 \mu \mathrm{m}$ in diameter.

Perichaena depressa is easy to recognize by the flat polyhedral sporangia; upon dehiscense upper part forms a distict lid, lower part a shallow cup.

Specimen MH 3909 grew mixed with Perichaena chrysosperma and Physarum diderma.

According to Neubert et al. (1993), Perichaena depressa usually grows on deciduous trees.

Arcyria cinerea (Bull.) Pers.

5b:3913 MH mc, 18b:3861 MH, 11n:3848 MH, 35:3790 MH, 635 TS.

Three collections in the field from montane forest, one from submontane rain forest; on decaying wood. One specimen from moist chamber culture from submontane belt; on Plumeria, mixed with Diderma hemisphaericum.

\section{Arcyria denudata (L.) Wettst.}

11n:3831A MH, $3850 \mathrm{MH}$, 11o:3836 MH, 27e:3813 MH, $3816 \mathrm{MH}, 3823 \mathrm{MH}, 35: 3797$ $\mathrm{MH}, 41: 3829 \mathrm{MH}$. Four specimens from montane forest, one from miombo woodland (in Malawi) and three from lowland rain forest; on decaying wood.

\section{Arcyria minuta Buchet}

39:613 TS. One specimen from miombo woodland; on litter.

Reported from many parts of the world. Described from Madagasgar (Patouillard 1928), reported from many parts of Africa.
Sporangia in small clusters, $1-1.5 \mathrm{~mm}$ tall, bright rose to salmon-pink, cylindrical, tapering upwards. Peridium evanescent; calyculus shallow, shining rosy, smooth or delicately papillate inside, the papillae sometimes connected by low ridges. Stipe short, concolorous with the sporangia or brownish red, filled with sporelike cells. Hypothallus thin, rosy to brownish red, shining, sometimes extending under the entire cluster. Capillitium firmly attached to the peridial cup, not very elastic; tubes $2-5 \mu \mathrm{m}$ in diameter, ornamented with large spines and warts and some half-rings, smoother in the basal part of the sporangium. Spores pink to salmon-pink in mass, colourless in transmitted light, globose, nearly smooth, by oil-immersion very minutely warted, $8-\underline{9.5}-10 \mu \mathrm{m}$ in diameter.

The spore diameter given in the literature varies: Neubert et al. (1993) 6-8(-10) $\mu \mathrm{m}$, Martin \& Alexopoulos (1969) 8-10 $\mu \mathrm{m}$ and Nannenga-Bremekamp (1991) (6-)8-10(-12) $\mu \mathrm{m}$. Neubert and Nannenga-Bremekamp (1979) revised $A$. minuta and stated that $A$. gulielmae Nann.-Bremek. is a synonym of $A$. minuta. The name $A$. gulielmae was created to replace the name $A$. carnea (G.Lister) G.Lister (NannengaBremekamp 1971). The information on the distribution of $A$. minuta in the present paper is according to the species concept of Neubert \& Nannenga-Bremekamp (1979).

Arcyria minuta can be distinguished from the other similar looking species of Arcyria as follows: A. insignis Kalchbr.\& Cooke has smaller spores and the capillitial threads are ornamented with transverse bands and spines arranged in a loose spiral. The capillitium of $A$. incarnata (Pers.) Pers. is not firmly attached to the calyculus. A. cinerea (Bull.) Pers. is never salmon coloured. A. corymbosa Farr \& Martin stands in clusters of 2-20 on fused (but individual) stalks; the capillitial ornamentation is blunt papillae or cogs and sometimes weak spirals, and the spores are marked with scattered or loosely grouped prominent warts and faint lines.

\section{Arcyria obvelata (Oeder) Onsberg}

110:3837 $\mathrm{MH}$. One specimen from montane forest, on decaying wood. 


\section{Arcyria pomiformis (Leers) Rostaf.}

26a:3586B $M H$ mc, 26c:3564 MH mc. One specimen from lowland, on Jacaranda, one from miombo on Pterocarpus angolensis. Reported from many parts of the world and of Africa. No earlier records from East Africa.

Sporangia scattered, stipitate, globose or somewhat prolate, ochraceous to pale ochraceous, up to $1.2 \mathrm{~mm}$ tall, expanding at maturity. Peridium fugacious except the shallow, plate-like calyculus, the inside of which is covered with papillae. The papillae are sometimes connected with short ridges forming a reticulum. Stalk erect, yellowish to pale brown, one-third to one-half (sometimes little longer) the total height, filled with spore-like cells. Hypothallus scanty. Capillitium ochraceous, firmly attached to the cup, net rather wide meshed, elastic; the tubules (2-)3-7 $\mu \mathrm{m}$ in diameter, marked with half-rings, spines and warts, which are sometimes locally connected by ridges into a reticulum. Spores brownish yellow in mass, almost colourless in transmitted light, spherical, nearly smooth with some scattered warts, $6.5-\underline{7.5}-8 \mu \mathrm{m}$ in diameter.

The stipe is relatively tall in both specimens. In one specimen ( $M H 3564)$ the capillitial tubules are thinner (2-)3-4 $\mu \mathrm{m}$ and the ornamentation is somewhat taller and not so dense. According to Nannenga-Bremekamp (1991), some small sporangia of Arcyria pomiformis have a very wide-meshed capillitial net, with wide tubes densely covered with warts. This description fits the other specimen $(M H 3586 B)$, which grew mixed with Licea bulbosa.

Arcyria pomiformis is common in moist chamber cultures, reported for example, on material collected from southern Finland (Härkönen 1979) and Turkey (Härkönen \& Uotila 1983).

\section{Hemitrichia calyculata (Speg.) M.L.Farr}

11n:3849 MH, 35:3789 MH, 3791 MH, 634 TS. Four specimens from montane forest; on decaying wood.

According to Alexopoulos \& Sáenz (1975), Hemitrichia calyculata is common and abundant in the tropics. Lister (1925) and Hagelstein (1944) believe $H$. calyculata to be an environmentally induced variant of $H$. clavata developed under warm temperature. Yamamoto et al. (1993) also consider $H$. calyculata to be a variant of $H$. clavata. According to them, var. clavata differs from var. calyculata in the gradually expanding stalk, in the deep, vase-like cup and in the easily detached capillitium. The capillitium of $H$. clavata is usually rougher than that of $H$. calyculata (Martin \& Alexopoulos 1969, Stephenson \& Stempen 1994). H. clavata is found only in the temperate zones. We have in total 35 specimens of $H$. calyculata from Tanzania, one from lowland forest but most from montane forest. To determine the range of the two taxa, spore to spore cultivations should be made.

\section{Trichia botrytis (J.F.Gmel.) Pers.}

2e:3596A $M H$ mc. One specimen from montane belt; on bark of Eucalyptus saligna. Widely distributed in temperate regions, in Africa earlier reported from northern and southern parts and from the Canary Islands.

Sporangia crowded, sessile, subglobose to clavate, brown with darker areas, $0.4-0.8 \mathrm{~mm}$ in diameter. Peridium rather thin, brown with darker thickened areas with granular matter. Capillitium composed of ochraceous brown elaters ornamented with spirals, about $5-7 \mu \mathrm{m}$ in diameter at the centre, tapering gradually to the long, slender tips. Spores ochraceous brown in mass, pale yellow by transmitted light, globose, minutely warted, $8-\underline{9.3}-10 \mu \mathrm{m}$ in diameter.

The peridium, capillitium and spores are like those of Trichia botrytis although the speices is usually stipitate.

The specimen grew mixed with Echinostelium minutum.

Only two Trichia species have been found earlier in Tanzania: one of them, T. decipiens, was found by Eichelbaum (1906) in the East Usambara Mountains and the other, $T$. favoginea, by Härkönen \& Saarimäki (1991), also in montane conditions. The genus Trichia is commonly considered rarer in warm than in cooler climates (Eliasson 1991, Farquharson \& G. Lister 1916, Farr 1969, Gottsberger 1968, Ing \& McHugh 1968).

\section{Order Stemonitales}

Forty-eight specimens of the order Stemonitales were collected in Tanzania in 1988-1991. 
These specimens belong to the following genera: Diachea (1), Leptoderma (1), Lamproderma (4), Comatricha (3), Stemonitis (32) and Stemonitopsis (7).

\section{Diachea leucopodia (Bull.) Rostaf.}

30a:3783 $\mathrm{MH}$. One specimen from montane forest; on litter.

Cosmopolitan. Reported from almost every part of Africa.

Sporangia in large groups, stipitate, cylindric, blunt at the tip and base, iridescent bronze and blue; often the bronze zone is at the base and tip and the blue zone in the middle of the sporangia; total height $1-2 \mathrm{~mm}$. Peridium thin, partially persistent, iridescent. Stipe white, erect, limy, having an expanded base, about one-half the total height. Hypothallus thin, white, calcareous. Columella thick, white, containing lime, nearly reaching the top of the sporangium. Capillitium rising from the whole length of the columella, composed of thin, branching and anastomosing brown threads which become paler at the periphery. Spores blackish brown in mass, relatively pale brown in transmitted light, globose, minutely warted, 8- $\underline{8.9}-10 \mu \mathrm{m}$ in diameter.

\section{Leptoderma iridescens G.Lister}

5b:3914 $M H$ mc. One specimen from submontane belt; on bark of Plumeria. Reported from Europe and U.S.A. New to Africa.

Fructifications sporangiate, loosely gregarious, pulvinate, sessile on a restricted base, sometimes short stipitate, greyish brown, 0.5-0.7 $\mathrm{mm}$ in diameter. Peridium membranous, greyish brown, somewhat iridescent, wrinkled, enclosing lime granules. Stipe, if present, very short and thick, concolorous with the sporangia. Columella absent. Capillitium of stout, simple or scarcely branching threads, dark brown in the middle, hyaline and tapering at the tips, having colourless or dark expansions and some fusiform swellings enclosing granular material; threads c. 1.5-2 $\mu \mathrm{m}$ thick. Spores dark brown in mass, darkish brown in transmitted light, globose, coarsely and irregularly spiny, spines partially in rows, $10-\underline{10.6}-13 \mu \mathrm{m}$ in diameter.

\section{Lamproderma arcyrionema Rostaf.}

19:3570A $M H$ mc. One specimen from lowland rain forest on bark of Cocos nucifera.

\section{Lamproderma scintillans (Berk. \& Br.) Morgan}

30a:3781B MH. One specimen from montane forest. On litter. Mixed with Physarum mutabile and Didymium nigripes.

\section{Comatricha nigra (Pers.) Schroet.}

37:3811 MH. One specimen from montane forest. On decaying wood.

Stemonitis axifera (Bull.) Macbr.

35:3792 MH. One specimen from montane forest. On decaying wood.

\section{Stemonitis fusca Roth}

36:3808 $\mathrm{MH}$. One specimen from montane forest. On decaying wood.

\section{Stemonitis splendens Rostaf.}

40:3828 $\mathrm{MH}$. One specimen from miombo (in Malawi), on a decaying stump.

\section{Order Physarales}

Altogether 179 specimens of the order Physarales were collected in Tanzania in 19881991. The specimens belong to the following genera: Badhamia (1), Badhamiopsis (1), Fuligo (17), Craterium (20), Physarella (3), Physarum (91), Diderma (8) and Didymium (38).

Badhamiopsis ainoae (Yamash.) Brooks \& Keller syn. Badhamia ainoae Yamash.

10c:3589A MH mc. One specimen from lowland; on Araucaria cunninghamii. Reported from North America, Hawaiian Islands and Japan. The only earlier African record in is from the Canary Islands (Bañares Baudet \& Beltrán Tejera 1987).

Sporangia scattered, sessile, subglobose to pulvinate, flattened, greyish brown; 0.3-0.8 
$\mathrm{mm}$ in diameter. Peridium one-layered, membranous, translucent, shiny, grey brown. Columella absent. Capillitium composed of tubular, calcareous columns, simple or scarcely branched, extending from the upper part of the peridium to the base. Spores dark brown in mass, brown in transmitted light, globose, evenly spiny, 9-9.1-10 $\mu \mathrm{m}$ in diameter.

Keller \& Brooks (1976) described a new genus for this species, which earlier was known as Badhamia ainoae. Badhamiopsis differs from Badhamia in having flat, effused plasmodiocarps and especially in having tubular columns of capillitium. Keller and Brooks (1976) remark that there is considerable variation in the shape and colour of fructifications. Peridial lime may be absent and then the fructifications are dark brown. This was the case in the collection from Tanzania.

Eliasson (1991) reported this species from Hawaii from moist chamber on bark from the base of a living coconut palm.

The specimen grew mixed with Licea tanzanica.

\section{Fuligo cf. cinerea (Schw.) Morgan}

32:3864 MH. One specimen from montane forest. On dead banana leaves. Cosmopolitan, from Africa reported from northern, western and southern parts.

Fructifications crowded, heaped, irregular in shape, pale grey to greyish white. Hypothallus cream-white, strand-like, branching. Cortex not observed, peridium fragile, covered with white lime nodes or scales, translucent after spores are gone. Capillitium nearly badhamoid, composed of tubules forming a net with a few thin, hyaline threads, lime nodes angular or irregular in shape. Spores black in mass, darkish brown in transmitted light, subspherical to ellipsoid 16-16.6-18 x 12-13.4-14 $\mu \mathrm{m}$, warted to spinulose.

Except for missing cortex, the specimen resembles Fuligo cinerea. It looks similar to that described in the figure-table (no. 75) of $F$. cinerea in Listr's monograph (1925). According to Lister (1925) and Nannenga-Bremekamp (1991), the cortex may sometimes be absent. Also the spores agree with those of $F$. cinerea. In some respects the specimen resembles Physarum didermoides (Pers.) Rostaf., which however has a double peridium and the spores are often angular or irregular in shape. Badhamia cinerascens Martin has spherical or nearly spherical spores (Martin \& Alexopoulos 1969).

\section{Fuligo septica (L.) Wiggers}

27e:3814 MH, 35:3795 MH, 36:3804 MH, 3805 MH, 3807 MH, 644 TS, 645 TS, 646 TS. Seven specimens from montane forest, one from lowland rain forest. Two on decaying wood, six on litter.

\section{Craterium aureum (Schum.) Rostaf.}

11n:3842 MH, $3844 \mathrm{MH}, 930 B \mathrm{TS}, 938 \mathrm{ATS}$, 939A TS, $940 \mathrm{TS}$, 110: $3832 \mathrm{MH}$, $918 \mathrm{~A} \mathrm{TS}$. 35:3794. All collections from lower montane forest. One specimen on twigs, all others on fallen leaves. Cosmopolitan. No earlier records from eastern Africa.

Sporangia gregarious, stalked, subglobose or obovoid, yellow to greenish yellow, 0.7-1.5 $\mathrm{mm}$ tall. Peridium thin with yellow lime granules or scales; at maturity breaking up irregularly with a circumscissile crack leaving the lower portion as a cup with an uneven rim. Stipe erect, grooved, about one third or a little less than half the total height, cream-coloured to yellowish, sometimes darker at the base; in transmitted light pale yellow, filled with lime or sometimes empty. Hypothallus thin, small. Capillitium composed of thin threads connected by relatively large, irregular, yellowish or white lime nodes which in some sporangia form a roundish pseudocolumella in the centre of the sporangium. Spores blackish brown to black in mass, brown in transmitted light, globose, minutely to very minutely warted, 7$\underline{8.5}-10.5 \mu \mathrm{m}$ in diameter.

According to Nannenga-Bremekamp (1991) it would be logical to place this species in the genus Physarum, close to Physarum flavidum, which has a distinctly double peridium and somewhat darker and larger spores than Craterium aureum.

In two specimens Craterium aureum grew mixed with $C$. leucocephalum and in two other mixed with Physarum melleum. 


\section{Craterium leucocephalum (Pers.) Ditmar}

11n:3841 MH, $3843 \mathrm{MH}, 3845 \mathrm{MH}, 3846 \mathrm{MH}$, 3847 MH, 930A TS, 110:978B TS, 33:3867 MH. Eight specimens, seven from montane forest, one from miombo woodland. On dead leaves.

\section{Physarum auriscalpium Cooke}

19:3570B $M H \mathrm{mc}$. One specimen from lowland rain forest on coconut palm. Reported from many parts of the world. Earlier records from Africa are from northern and southern parts of the continent.

Sporangium globose, very short stalked, lemonyellow. Peridium thin, fragile, with yellow lime scales, limeless at the base. Stipe very short, dark. Capillitium with yellow, angular or roundish lime nodes connected with short, thin hyaline threads, sometimes difficult to see. Spores black-brown in mass, brown in transmitted light, globose, warted, 12-12.4-13 $\mu \mathrm{m}$ in diameter.

The species frequently occurs on the bark of living trees in culture (Martin \& Alexopoulos 1969, Farr 1976). It has been reported from moist chamber cultures, e.g. from Dominica (Farr 1969) and from Turkey (Härkönen \& Uotila 1983, Härkönen 1987).

The specimen grew mixed with Lamproderma arcyrionema.

\section{Physarum bitectum G.Lister}

7:3603 $\mathrm{MH} \mathrm{mc}$. One specimen from semidesert Commiphora bush. On a fruitbody of Sarcosoma. Reported from many parts of the world. In Africa earlier from North, West and South Africa and from the Canary Islands.

Sporangia in groups, sessile, subglobose, 0.6$0.8 \mathrm{~mm}$ wide, cream-white. Peridium double, the outer layer a cream-white lime shell, the inner membranous, pale. Columella absent. Capillitium of thin, colourless threads with relatively large roundish, angular or branched white lime nodes. Spores black in mass, rather dark brown in transmitted light, globose, spiny, $10-10.8-11 \mu \mathrm{m}$ in diameter.

This species usually grows on dead leaves, twigs, compost heaps etc. From moist chamber cultures of bark of living trees it has been re- ported from Turkey, for example (Härkönen \& Uotila 1983).

Physarum compressum Alb. \& Schw.

2h:3597 MH mc, 11o:3831B MH, $3833 \mathrm{MH}$, $3838 \mathrm{MH}, 915 \mathrm{TS}, 29 \mathrm{a}: 3772 \mathrm{MH}, 29 \mathrm{~b}: 3773 \mathrm{MH}$, 31:3862 MH, 38:3820 MH. Eight specimens in the field from montane forest, two on twigs, six on plant debris, mostly dead leaves. One specimen from moist chamber culture on Juniperus procera from Ericaceous belt.

\section{Physarum crateriforme Petch}

7:3601A MH mc, 3604A MH mc, 26a:3560 $M H \mathrm{mc}$. Two specimens from semidesert, one on Delonix elata, the other on Commiphora. One specimen from lowland rain forest on Tectona grandis. Reported from U.S.A, the Caribbean, Europe, India, Sri Lanka and Japan. In Africa earlier reported from northern and western parts and from the Canary Islands.

Sporangia gregarious, stipitate or occasionally nearly sessile, globose, subglobose, or clavate, often depressed at the centre of the sporangia, being crateriform, sometimes also depressed beneath; 0.3-0.5 $\mathrm{mm}$ in diameter, $0.5-1 \mathrm{~mm}$ tall; pale-brown to greyish light-brown. Peridium thin, fragile, pale brown to greyish brown, yellowish brown inside; covered with pale brown lime granules. Stipe thick, darkbrown to black, about one half the total height of the sporangium or shorter, occasionally common for two sporangia; red brown in transmitted light, filled with refuse matter. Hypothallus concolorous with the stipe, small. Columella variable, often conspicuous, cylindric, extending to the apex of the sporangium, or shorter, conic; usually concolorous with the stipe; rarely lacking. Capillitial lime nodes rod-like, reaching horizontally from the peridium to the columella. Spores dark-brown in mass, brown in transmitted light, globose to subglobose, closely spiny, 10-12.1-14.5 $\mu \mathrm{m}$ in diameter.

There were some extra large spores (up to $20 \mu \mathrm{m})$ in one specimen $(M H 3604 A)$. The spore diameter is generally slightly larger than announced in the references $(10-13 \mu \mathrm{m})$, probably because the sporangia are somewhat immature. One specimen grew mixed with Physarum ovisporum, one with Diderma hemisphaericum. 


\section{Physarum diderma Rostaf.}

5b:3903 MH mc, 3907 MH mc. Two specimens from submontane rain forest. On Juniperus procera. Reported from U.S.A., Europe, Israel and India. An earlier report from Africa is from Morocco (Malençon \& Bertault 1967).

Sporangia clustered, subglobose or somewhat prolate, sessile, with a constricted base, white or dingy ochraceous white, $0.5-1 \mathrm{~mm}$ in diameter. Hypothallus white. Peridium of two layers, outer layer of fragile, rather thick white to dingy white lime, inner layer membranous, pale, shiny. Capillitium of numerous, large, roundish, white lime nodes connected with thin, hyaline threads, lime in some sporangia massed in centre to form a roundish pseudocolumella. Spores black in mass, dark brown in transmitted light, globose, densely spinulose, sometimes with clusters of darker spines, some spores with a pale smooth band, $11-\underline{13.1}-14.5 \mu \mathrm{m}$ in diameter.

One specimen ( $M H$ 3903) grew mixed with Perichaena corticalis var. corticalis.

\section{Physarum javanicum Racib.}

11n:3839 MH, $3840 \mathrm{MH}$. Two specimens from montane forest. On decaying wood.

\section{Physarum melleum (Berk. \& Br.) Massee}

11n:938B TS, 939B TS, 941 TS, 30a:3777 MH. Four specimens from montane forest. On dead leaves. Two specimens grew mixed with Craterium aureum.

\section{Physarum mutabile (Rostaf.) G.Lister}

11o:3835 MH, 29a:3776 MH, 30a:3778A MH, 3781A MH, 32:3863 MH, 33:3868 MH. Five specimens from montane forest, one from miombo woodland. Four on dead leaves, one on plant debris, one on living plant.

One specimen ( $M H$ 3781A) was somewhat immature and the peridial lime was exceptionally thick. In this specimen $P$. mutabile grew mixed with Lamproderma scintillans and $D i$ dymium nigripes. Another specimen grew mixed with Physarum perfectum.

\section{Physarum nucleatum Rex}

27e:3815 $\mathrm{MH}$. One specimen from lowland rain forest. On decaying wood.

\section{Physarum ovisporum G.Lister}

7:3601B MH mc. One specimen from semidesert. On Delonix elata. Reported from North America, Hawaiian Islands, Europe and Asia. In Africa earlier reported from northern and western Africa and from the Canary Islands.

Sporangia or short plasmodiocarps, sessile, white, $0.5 \mathrm{~mm}$ in diameter. Peridium thin, fragile, covered with white lime granules, less limy at the base. Capillitium with white, rounded and elongate lime nodes connected with thin, hyaline threads. Spores blackish brown in mass, brown by transmitted light, slightly oval to subglobose, densely spiny, with a pale band of dehiscence, 10-11.4-12 $\mu \mathrm{m}$ in diameter.

Physarum ovisporum is distinguished from the other similar looking species by the often oval spores with a pale line and the dark base of the peridium.

Härkönen (1979) has studied the probable type specimen of Physarum ovisporum and published a photo of the spores (specimen G.Lister 3097). The spores are similar in form to those of the Tanzanian specimen but somewhat larger. According to Hagelstein (1944), $P$. ovisporum is closest to $P$. vernum. Martin \& Alexopoulos (1969) doubted the validity of $P$. ovisporum. According to Farr (1976), P. ovisporum is a synonym to $P$. vernum. $P$. ovisporum, $P$. vernum and $P$. cinereum form a group of species, the differences of which need to be examined in detail. This specimen grew mixed with Physarum crateriforme.

\section{Physarum perfectum M.E.Peck}

11n:857B TS, 30a:3778B MH. Two specimens from lower montane forest. On litter. Reported from temperate regions. New to Africa.

Sporangia gregarious, stipitate to nearly sessile, globose, pale grey to grey. Peridium thin, shiny, translucent after the spores are gone; sparsely covered with lime granules, which sometimes are connected with short ridges. Stalk white, short, rather thick, slightly tapering upwards, limy. Hypothallus rather small, 
thin, colourless. Columella distinct, white, conic, about one-third the height of the sporangium. Capillitium composed of thin, translucent threads, with numerous angular to branched or rounded white lime nodes, some of which are occasionally massed to a small central body. Spores blackish brown in mass, pale brown in transmitted light, globose, covered with fine warts, $8-\underline{8.8}-10 \mu \mathrm{m}$ in diameter.

Close to Physarum melleum, the sporangia of which range widely in colour and sometimes are almost totally grey, approaching $P$. perfectum. Well-developed columella and slightly larger spores distinguish $P$. perfectum.

One specimen grew mixed with Physarum mutabile, one with $P$. pusillum.

\section{Physarum pusillum (Berk. \& Curt.) G.Lister}

11n:857A TS, 35:3798 MH, 3799A MH. Three specimens from montane forest. On dead leaves and twigs. One specimen grew mixed with Physarum perfectum, one with Didymium clavus.

\section{Physarum stellatum (Massee) Martin}

35:3788 MH, $3793 \mathrm{MH}$. Two specimens from lower montane forest. On decaying wood. Common in the tropics. Earlier records from Africa are from Liberia (Farr 1959) and Nigeria (Ing \& McHugh 1968).

Sporangia gregarious, stipitate, globose or somewhat depressed, erect or nodding, sometimes umbilicate below, white to greyish white. Peridium thin, shiny translucent, with white lime granules on the surface; at maturity dehiscing in floriform fashion. Stalk rather long and slender, tapering upward, calcareous, light brown or yellowish, dark at the base, at the tip sometimes almost white; groovy. Hypothallus inconspicuous. Capillitium delicate, almost colourless with a few small, oval or subfusiform nodes, most nodes massed in the centre forming a white, round pseudocolumella. Spores brown in mass, pale brown by transmitted light, globose, delicately warted, 8- $\underline{8.8}-9.5 \mu \mathrm{m}$ in diameter.

Physarum stellatum resembles $P$. globuliferum and $P$. nutans, but clearly differs from both in the central lime ball, which after dehiscence easily falls out. From $P$. nucleatum it differs in the more delicate capillitium with few subfusiform lime nodes and in the calcareous stalk.

\section{Physarum vernum Somm.}

21:3598 $M H$ mc, 30a:3786 MH. One specimen from montane forest. On litter. One specimen from moist chamber, on Diospyros abyssinica from Ericaceous belt; the specimen grew on the side of the petri dish. Reported from many parts of the world. No earlier records from eastern Africa.

Sporangia crowded, sometimes heaped, sessile, globose to subglobose varying to short plasmodiocarps, white to greyish white. Peridium single, fragile, usually rather densely covered with white lime granules. Hypothallus inconspicuous. Capillitium a net of thin, hyaline tubules with many white, oblong and rounded lime nodes, nodes occasionally massed to the centre forming a roundish pseudocolumella. Spores blackish brown in mass, rather pale brown to dark purple brown in microscope, minutely or sometimes distinctly warted, warts occasionally connected with ridges, 9.5-10.4$12 \mu \mathrm{m}$ in diameter.

This species is very close to Physarum cinereum. The main differences are the usually more plasmodiocarpous sporocarps, more limy peridium and the darker and slightly larger spores of $P$. vernum (Martin \& Alexopoulos 1969). Martin \& Alexopoulos (1969) mention that the capillitial lime nodes sometimes mass in the centre forming a pseudocolumella, but Nannenga-Bremekamp (1991) disagrees. The specimen collected in the field is assigned with some hesitation to $P$. vernum. The fructifications are sporangiate to very short plasmodiocarps, and in spite of the dark spore mass the spores are relatively pale brown by transmitted light. On the other hand, there is a pseudocolumella, and the peridium is relatively calcareous. Evidently this is an intermediate form.

\section{Physarum cf. virescens Ditmar}

36:3819 $\mathrm{MH}$. One collection from montane forest, alt. $1900 \mathrm{~m}$. On a fallen leaf. Mostly reported from temperate regions. In Africa earlier reported from northern parts and from the Canary Islands. 
Sporangia crowded or heaped in small clusters, partially nearly plasmodiocarpous, sessile or with weak, strand-like stalk, subglobose, ovoid or prolate, or partially merged at the base and then branched. Peridium membranous, fragile, covered with greenish yellow lime granules. Hypothallus colourless. Columella none. Capillitium composed of delicate, hyaline threads with yellow, angular and branched lime nodes. Spores dark brown in mass, pale brown by transmitted light, covered with small warts, $6.5-\underline{6.9}-7.5 \mu \mathrm{m}$ in diameter.

In appearance this specimen resembles Physarum virescens, but the spores are smaller and paler, and like the spores of Fuligo septica. The spore size of $P$. virescens is $8-10 \mu \mathrm{m}$ for Martin \& Alexopoulos (1969) and Farr (1976), 7-10 um for Nannenga-Bremekamp (1991) and Emoto (1977). According to Emoto the spores are covered with spines, but the other three describe them as minutely punctate or warted. In the specimen examined here the spores were minutely warted. $P$. obscurum is close to $P$. virescens with spores $6-8 \mu \mathrm{m}$ in diameter. The sporangia are scattered rather than heaped however, olivaceous rather than greenish-yellow and larger, and the capillitium contains non-limy threads producing a more rigid network (Ing 1982).

\section{Diderma effusum (Schw.) Morgan}

19:3569 $M H$ mc. One specimen from moist chamber culture of bark of Cocos nucifera from lowland rain forest. The specimen grew on the lid of the petri dish.

\section{Diderma hemisphaericum (Bull.) Hornem.}

5b:3912 MH mc, 7:3604B MH mc, 29a:3775A $\mathrm{MH}, 30 \mathrm{~b}: 3784 \mathrm{MH}$.

Two field collections, both from montane forest on dead leaves. One specimen grew mixed with Didymium squamulosum. Two specimens from moist chamber cultures: one, mixed with Arcyria cinerea, on bark of Commiphora from semidesert bushland, the other on bark of Plumeria from submontane belt. Diderma hemisphaericum has been reported from moist chamber cultures earlier, e.g. from Dominica (Farr 1969), Burma (Reynolds \& Alexopoulos 1971) and Gambia (Härkönen 1981).

\section{Didymium anellus Morgan}

7:3605 $\mathrm{MH} \mathrm{mc}$. One specimen from semidesert bushland. On stalk of living Euphorbia heterochroma. From Africa earlier reported from Angola (Almeida 1973) and Gambia (Härkönen 1981).

Sporangia or short plasmodiocarps, sessile on a constricted base, pulvinate to flat-pulvinate, occasionally umbilicate above. Peridium covered with dirty white lime nodes, membranous, translucent. Columella absent or represented by a deposit at the base of sporangium. Capillitium composed of slender, more or less dark threads, simple or branching. Spores dark brown in mass, brown by transmitted light, evenly minutely spinulose, $7.5-\underline{7.9}-8.5 \mu \mathrm{m}$ in diameter.

\section{Didymium bahiense Gottsb.}

38:3821 $M H$. One specimen from montane forest. On fallen leaves.

\section{Didymium clavus (Alb. \& Schw.) Rab.}

35:3799B $M H$. One specimen from lower montane forest. On decaying twigs. Widely distributed in the world. Earlier records from Africa from northern, western and central parts and from the Canary Islands.

Sporangia gregarious, stipitate, discoid, umbilicate at the base, sometimes also above, white to greyish white, up to $1 \mathrm{~mm}$ tall. Peridium thin, dark, shiny, covered with white stellate lime crystals. Stipe rather thick, short, erect, tapering upwards, black; red-brown in transmitted light, filled with refuse matter. Hypothallus thin, discoid, brown, rather wide. Columella none. Capillitium composed of thin, brown, sparsely dichotomously branched threads, covered irregularly with nodules. Spores dark brown in mass, pale greyish brown by transmitted light, globose, very delicately warted (oil-immersion), some spores with small groups of warts; $6-\underline{6.5}-7 \mu \mathrm{m}$ in diameter.

Didymium clavus is usually easily recognized by the discoid shape and by the thickened, black base of the peridium. In this specimen the dark basal plate is absent. All other features (discoid shape, black stipe and small, pale, very minutely warted spores), however, refer to this species. 
Didymium clavus grew mixed with Physarum pusillum.

\section{Didymium minus (A.Lister) Morgan}

11n:929 TS, 30a:3787 MH, 34:3869 MH. Two specimens from montane forest, one from miombo woodland. On dead leaves.

\section{Didymium nigripes (Link) Fr.}

30a:3781C $M H$. One scanty specimen from montane forest on litter. Mixed with Physarum mutabile and Lamproderma scintillans.

Didymium squamulosum (Alb. \& Schw.) Fr.

11o:916 TS, 29a:3775B MH, 30b:3785 MH, 32:3865 MH, $3866 \mathrm{MH}$.

Five specimens from montane forest. Four on dead leaves, one on twigs. One specimen grew mixed with Diderma hemisphaericum.

\section{Didymium sp.}

27e:3818 $\mathrm{MH}$. One specimen from lowland rain forest. On dead leaves of Pandanus.

Sporangia gregarious, stipitate, subglobose, white, erect to slightly nodding. Peridium fragile, thin, translucent, covered with white stellate lime crystals; dehiscing into lobes. Stalk erect, tapering, furrowed, pale to nearly white, filled with rhomboid lime. Hypothallus minute, discoid, white. No columella. Capillitium composed of thin, hyaline, scarcely branching threads. Spores black in mass, darkish brown in transmitted light, globose, densely spiny with groups of darker spines, $8-\underline{8.5}-9 \mu \mathrm{m}$ in diameter.

The white, limy stalk with rhomboid lime granules (peridial lime is stellate) is an unusual feature in the genus Didymium. D. intermedium has rhomboid lime, but the spores are totally different, larger and spiny with irregular reticulation. The present specimen somewhat resembles $D$. squamulosum, which is more robust and has a columella.

\section{Distribution and habitats of the Tanzanian Myxomycetes}

About one third of the Myxomycetes are more or less cosmopolitan. Some of them, however, prefer a certain kind of climate (Gray \& Alexopoulos 1968). One group of species is more abundant in the tropics or subtropics and in warm temperate regions. Among these species at least Badhamia gigantospora, Ceratiomyxa spaerosperma, Hemitrichia calyculata, Physarum bogoriense, $P$. melleum, $P$. nucleatum, $P$. pezizoideum, $P$. stellatum and $P$. superbum have been found in Tanzania (see also Härkönen \& Saarimäki 1991, Ukkola \& Härkönen 1996). According to Gray \& Alexopoulos (1968), also strictly tropical species exist. Of these species, Physarum javanicum and Tubifera bombarda occur in Tanzania.

Of the specimens collected in the field in Tanzania in 1990-1991, eleven originated from lowland (mainly rain forest, under $800 \mathrm{~m}$ ). Only three specimens were from submontane rain forest $(800-1000 \mathrm{~m})$, and none was from the Ericaceous belt (above $2400 \mathrm{~m}$ ).

Most of the Myxomycetes were found in montane forest. This was also the case in earlier field work (Härkönen \& Saarimäki 1991). About $60 \%$ of Tanzania is covered by wooded savannas, miombo woodlands (Niemelä 1988). The miombo trees shed their leaves during the dry season, and in the rainy season tall grass covers the ground. Most miombo trees form mycorrhiza with fungi of Basidiomycetes and at the beginning of the rainy season a rich variety of fungal fruit bodies appear. In spite of an eager search, only six specimens of Myxomycetes were found in miombo woodland in the field. Two of these were found in Malawi. Fire may be the major reason for the rarity. In addition to natural fires, the local people have a tradition of setting fire to the dead grass of the previous growing season. Thus there is very little litter or dead wood available. Similarly in Nigeria, slime mould specimens in savanna and dry grassland have been few (Ing 1964, Ing \& McHugh 1968). Maimoni-Rodella \& Gottsberger (1980) have studied Myxomycetes in Botucatu, Brazil. Slime moulds were investigated during a one-year study (1976-1977) in an evergreen forest and in a savanna-like cerrado. Twenty-three species of Myxomycetes were found in the cerra- 
do and twenty in the forest. The cerrado area had not been burned for at least eight years.

Bark samples for moist chamber cultures were collected from localities where no fruitbodies of Myxomycetes were found. Therefore only $13 \%$ of the bark samples originated from montane forests. Most of the samples were collected in the Ericaceous belt and in lowland and submontane belt, a few from the semidesert (Commiphora) bushland and three from miombo. The Ericaceous belt is a barren and cool habitat for slime moulds; from the 95 moist chamber cultures prepared from bark samples collected from the belt, we harvested only five specimens. Possibly also the high UVradiation in this vegetation belt contributes to the rarity of the Myxomycetes. Seven specimens were found from the twelve moist chamber cultures prepared of bark samples collected from semidesert. Although semidesert is an arid habitat it is warm, and during the onset of rains the dormant spores of slime molds probably germinate very quickly. All three bark samples collected in miombo produced Myxomycetes (two species).

Fig. 11 shows all the specimens collected in Tanzania in 1988-1991 distributed by vegetation belt. The column for montane forest is by far the highest.

\section{Substrata}

For the whole life-cycle of slime moulds to appear requires proper moisture and the availability of decaying plant material (Martin \& Alexopoulos 1969). According to Gray \& Alexopoulos (1968), the quality of the substratum is less important. Some species nevertheless, occur more frequently on certain substrata. Of the 162 specimens examined in this study (collections in 1990-1991), 67 grew on litter and 44 on decayed wood. Specimens on bark of living trees numbered 51, all of them harvested from moist chamber cultures. Fifteen of these grew on coniferous bark and 31

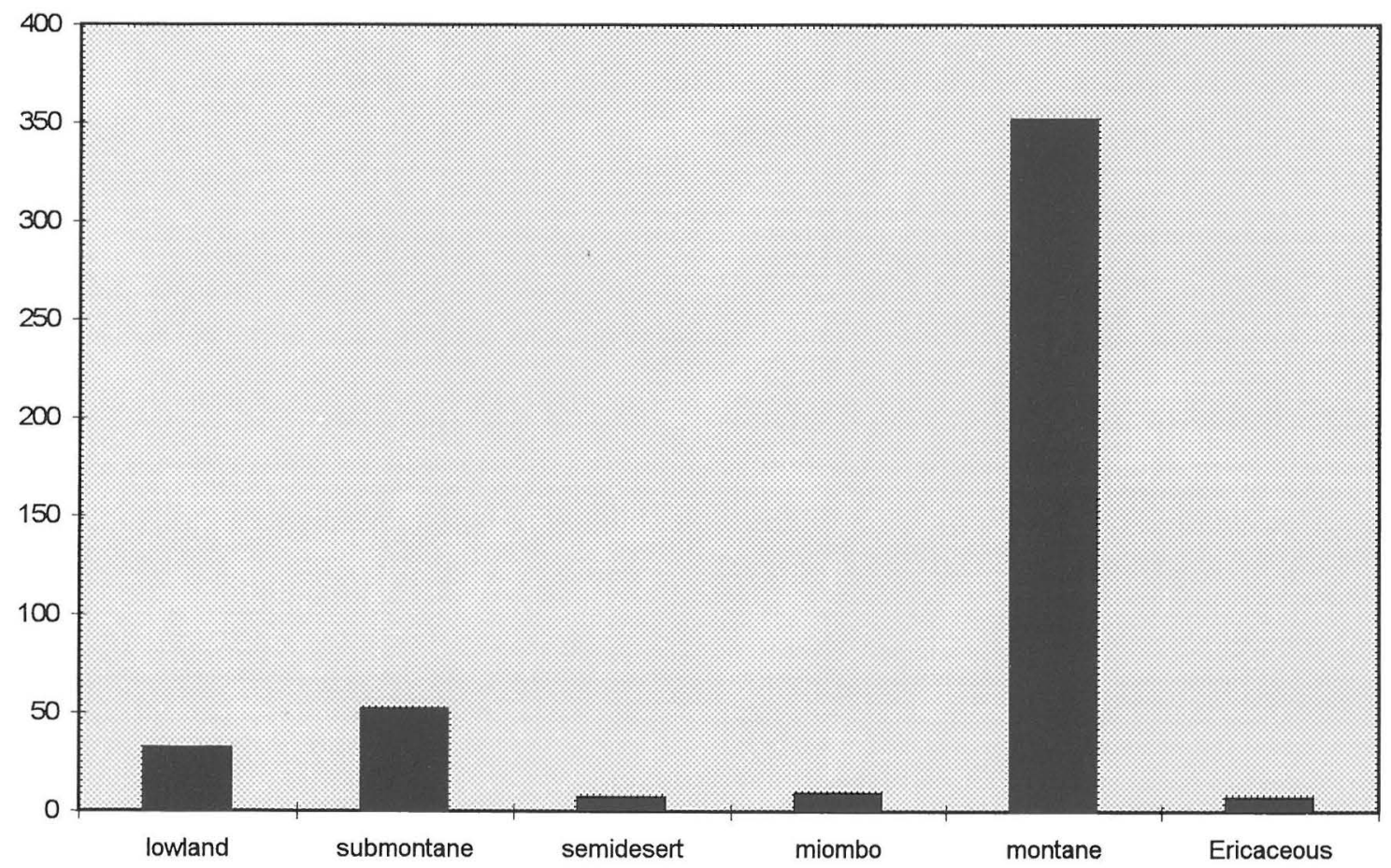

Fig. 11. Myxomycete specimens collected in Tanzania (including two specimens in Malawi) in 1988-1991, distributed by vegetation belt. Lowland $=$ under $800 \mathrm{~m}$ (mainly rain forest); submontane $=$ submontane rain forest, $800-1000 \mathrm{~m}$; semidesert, mainly of Commiphora bushland; miombo = miombo woodland, 850-1150 (-1600) m; montane = montane forest, alt. 1000-2400 (-3000) m; Ericaceous = Ericaceous belt, alt. above $2400 \mathrm{~m}$. 


\begin{tabular}{|c|c|c|c|c|c|c|}
\hline \multicolumn{5}{|c|}{ HOST TREE } & \multirow{2}{*}{$\begin{array}{l}\mathrm{pH} \text { of the } \\
\text { substrate }\end{array}$} & \multirow{2}{*}{$\begin{array}{c}\text { incubation time } \\
\text { in days }\end{array}$} \\
\hline & $\begin{array}{c}\text { coniferous } \\
15\end{array}$ & $\begin{array}{c}\text { deciduous } \\
31\end{array}$ & $\begin{array}{c}\text { palm } \\
3\end{array}$ & $\begin{array}{c}\text { Euphorbia } \\
\mathbf{1}\end{array}$ & & \\
\hline Oder Liceales & 6 & 13 & & & $5.1-7.4$ & $4-13$ \\
\hline Cribraria minutissima & & 1 & & & 5.1 & 4 \\
\hline Licea biforis & 1 & & & & 6.4 & 7 \\
\hline Licea bulbosa & & 6 & & & $6.1-7.1$ & $4-11$ \\
\hline Licea parasitica & 1 & 1 & & & $6.4-6.7$ & $4-7$ \\
\hline Licea cf. pedicellata & 1 & & & & 7.4 & 9 \\
\hline Licea tanzanica & 3 & 5 & & & $5.5-6.7$ & $4-13$ \\
\hline Order Echinosteliales & 0 & 2 & & & $4.7-6.4$ & \\
\hline Echinostelium minutum & 2 & & & & $4.7-6.4$ & 9-? \\
\hline Order Trichiales & 5 & 7 & & & $4.3-7.7$ & $4-73$ \\
\hline Arcyria cinerea & & 1 & & & 6.1 & 30 \\
\hline Arcyria pomiformis & & 2 & & & $4.3-7.1$ & $4-?$ \\
\hline Calomyxa metallica & & 1 & & & 6.7 & 8 \\
\hline Perichaena chrysosperma & 1 & & & & 7.3 & 23 \\
\hline${ }^{*}$ Perichaena corticalis & 2 & 2 & & & $6.5-7.4$ & $4-30$ \\
\hline Perichaena depressa & 2 & & & & $6.3-7.3$ & $23-73$ \\
\hline Trichia botrytis & & 1 & & & 4.7 & $?$ \\
\hline Order Stemonitales & 0 & 1 & 1 & & $5.5-6.2$ & 32-? \\
\hline Lamproderma arcyrionema & & & 1 & & 5.5 & 32 \\
\hline Leptoderma iridescens & & 1 & & & 6.2 & $?$ \\
\hline Order Physarales & 4 & 8 & 2 & 1 & $5.1-7.7$ & $7-32$ \\
\hline Badhamiopsis ainoae & 1 & & & & 6.7 & 4 \\
\hline Diderma effusum & & & 1 & & 5.7 & 32 \\
\hline Diderma hemisphaericum & & 2 & & & $?$ & $8-30$ \\
\hline Didymium anellus & & & & 1 & 7.4 & 8 \\
\hline Physarum auriscalpium & & & 1 & & 5.5 & 32 \\
\hline Physarum bitectum & & 1 & & & 6.5 & 11 \\
\hline Physarum compressum & 1 & & & & 5.1 & 31 \\
\hline Physarum crateriforme & & 3 & & & $5.9-6.4$ & $7-11$ \\
\hline Physarum diderma & 2 & & & & $7.2-7.3$ & $23-30$ \\
\hline Physarum ovisporum & & 1 & & & 6.4 & 11 \\
\hline Physarum vernum & & 1 & & & 6.5 & 16 \\
\hline
\end{tabular}

Fig. 12. Myxomycete species harvested from bark of living Tanzanian trees in moist chamber cultures. * In one Perichaena corticalis collection the tree species is not mentioned. 


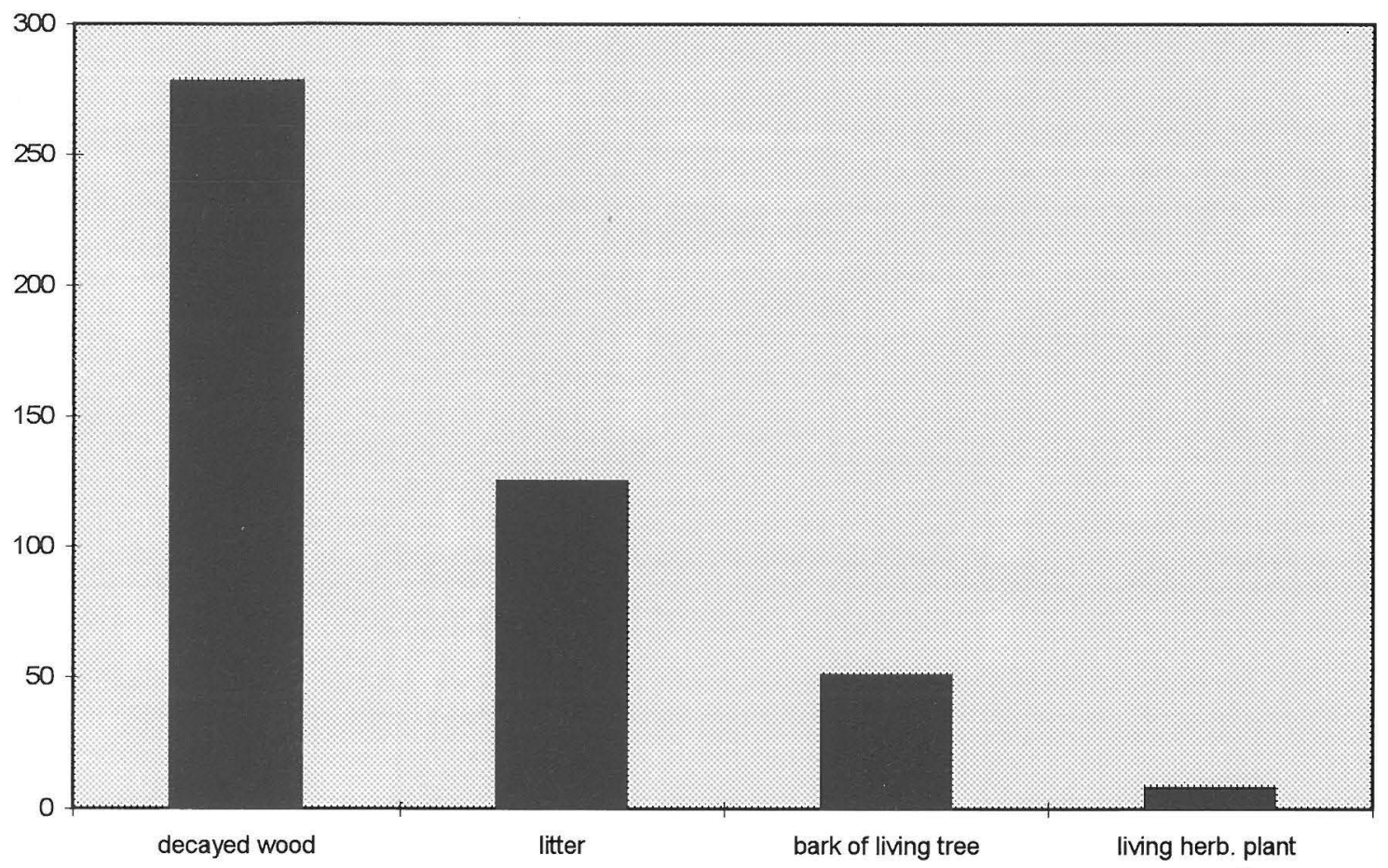

Fig. 13. Number of Myxomycete specimens collected on different substrata in Tanzania and (two specimens) Malawi 1988-1991. Living herb. plant $=$ living herbaceous plant.

Fig. 14. Number of specimens in the six orders of Myxomycetes on different substrata. The diagram includes all (cited) collections in Tarzania, and two in Malawi, in 1988-1991.

Living herb. plant $=$ on living, herbaceous plant.

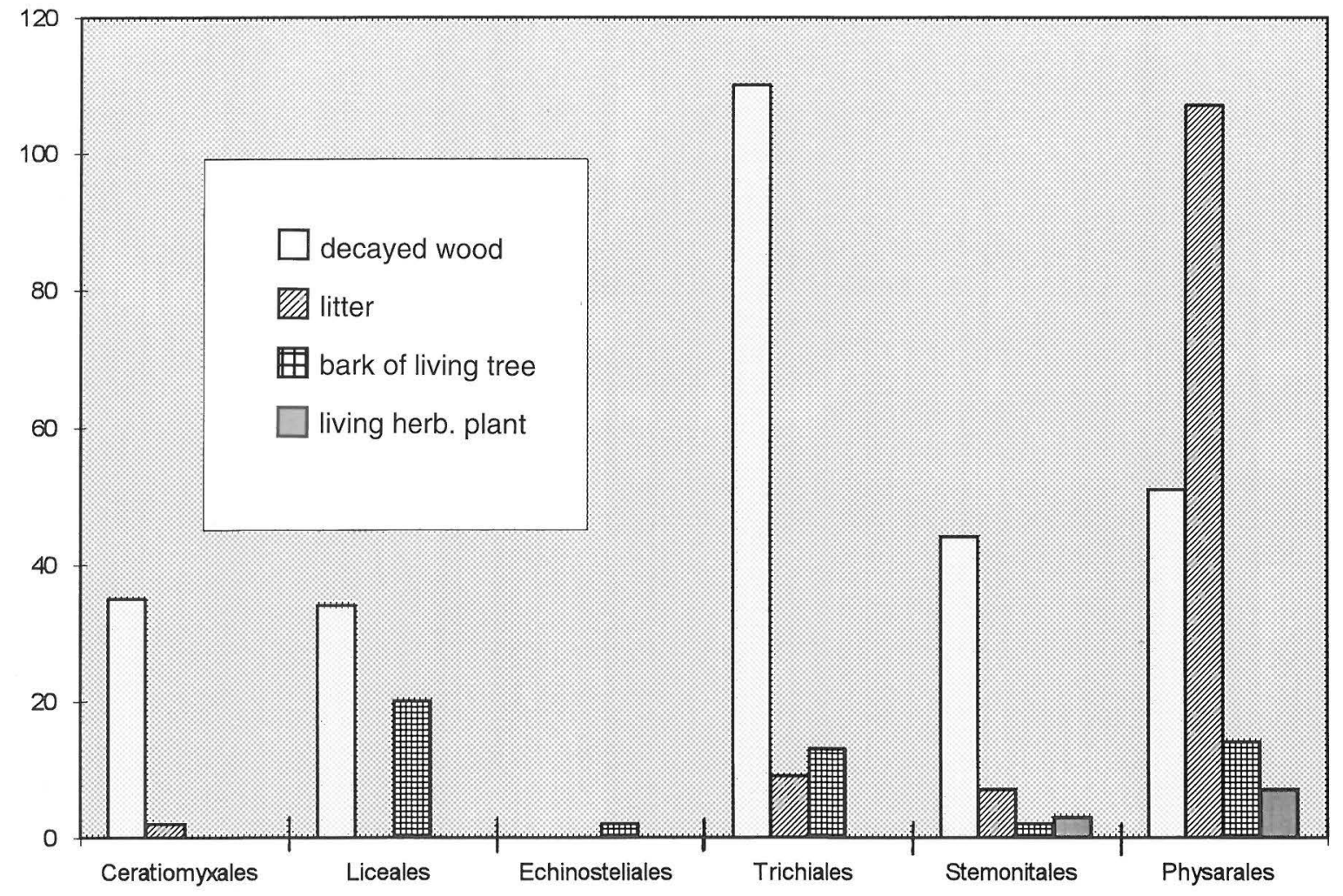


on deciduous bark, three grew on a palm tree (Cocos nucifera) and one on Euphorbia heterochoroma. In this case the result does not reveal a preference for deciduous trees as substrata because the majority of our bark collections were from deciduous trees. Champion \& Mitchell (1980) have noticed that in the Canary Islands specimens of bark from deciduous trees yield relatively better results than those collected from trees of evergreen forests.

The $\mathrm{pH}$ values of substrata of the moist chamber cultures with bark of living Tanzanian trees can be seen in Fig. 12. In the most acid substrata ( $\mathrm{pH} 4.3-4.7$ ), Echinostelium minutum, Trichia botrytis and Arcyria pomiformis were found, and in almost neutral conditions ( $\mathrm{pH}$ 7.2-7.4) Licea of. pedicellata, Physarum diderma and Didymiun anellus. These results agree fairly well with those of Härkönen \& Uotila (1983) for Turkey and of Stephenson (1989) for temperate forests in southwestern Virginia. In Stephenson's study the members of Liceales appeared to have a relatively wide $\mathrm{pH}$ tolerance, and the members of the Echinosteliales and the Stemonitales generally developed under more acid conditions than did members of the Trichiales and the Physarales. In this study, however, the widest $\mathrm{pH}$ tolerance is found in the Trichiales.

Fig. 13 shows the specimens collected in Tanzania in 1988-1991 distributed by substratum. The majority of the specimens grew on decayed wood.

Fig. 14 shows the number of specimens in the six orders of Myxomycetes on different substrata. The diagram includes all collections made in Tanzania in 1988-1991. Most of the orders show some preference for certain substrata. In general, for example, members of the orders Ceratiomyxales, Liceales, Trichiales and Stemonitales prefer decayed wood or the bark of living trees. In the case of Stemonitales there were even some specimens growing on living herbaceous plants. The members of the order Physarales grew on several kinds of substrata, most commonly on litter.

\section{Discussion}

Altogether 455 specimens of Myxomycetes were collected in Tanzania in 1988-1991. Two additional specimens were collected in neigh- bouring Malawi. The specimens represent 88 species, 12 of which are new to Africa, and one of twelve, Licea tanzanica, is new to science. The most abundant species in Tanzania was Ceratiomyxa fruticulosa. The most abundant genus was Physarum (91 specimens) and the most abundant order the Physarales (179 specimens). Including Eichelbaum's collections in 1903, a total of 91 species have been found in Tanzania.

According to Alexopoulos (1970), there are fever Myxomycetes in tropical rain forests than in temperate deciduous forests. Most Myxomycete specimens collected in the field in Tanzania during 1988-1991 were found in montane forests. The climate of this vegetation belt during the rainy season is not unlike the climate of the temperate or boreal zone during the growing season. The turnover of the litter and decaying wood is not so rapid as it is in the lowland rain forests, so there are substrata available for slime moulds. Although the quality of the substrata is usually not considered important, the Tanzanian material provides confirmation that certain species prefer certain substrata. The preference is even seen at the order level.

The ratio of the number of Myxomycete specimens harvested from moist chambers (51) to the number of moist chambers established (223) is not high. Comparable studies in West Africa in Gambia (Härkönen 1981) have given a figure of $71 \%$ and in Turkey (Härkönen \& Uotila 1983) as much as 116\%. The Gambian material was from lowland and comprised not only bark from living trees but several kinds of plant litter. Results for boreal bark material (Finland and Norway) gave a value of $45 \%$ (Härkönen 1979). Alexopoulos' (1953) studies in Florida gave rather similar results to ours in Tanzania: $23.8 \%$. The low ratio in the present study probably has to do with the vegetation belts from which the bark collections were made. Most of the collections were from the Ericaceous belt (above $2400 \mathrm{~m}$ ), which clearly is too exposed and cool an environment for abundant occurrence of Myxomycetes. Stephenson (1989) has studied Myxomycetes occurring on the bark of living trees in temperate forests in southwestern Virginia. The percentage, $90 \%$, of cultures yielding some stage of Myxomycetes is high compared to the corresponding presentage in this study, 36\% (in- 
cluding plasmodia that failed to produce mature fruiting bodies).

The identification of the material raised a number of problems as to the delimitation of some species, e.g. the group Physarum cinereum, $P$. vernum and $P$. ovisporum. The group Didymium nigripes, $D$. iridis and $D$. bahiense also needed a through revision. Härkönen and Saarimäki (1991) assigned six Tanzanian specimens to $D$. nigripes mainly on the basis of dark columelle and black stipes filled with refuse material at the base. Parts of some specimens were later sent to Prof. Jim Clark (University of Kentucky, U.S.A.) who is specialized in this $D i$ dymium group. Prof. Clark succeeded in cultivating one specimen of Didymium nigripes (Härkönen 3638) from spore to spore, and according to him, it produced descendants looking like typical $D$. iridis (Clark in litt. 1994). He believes that the differences between the two species are totally influenced by the environment and have no systematic value.

Acknowledgements. We wish to thank Dr. Harold Keller for studying the undescribed Licea species and late Mrs. N.E.Nannenga-Bremekamp for sending us the slides of the types of Licea bulbosa and L. rugosa. Herbarium specimens were obtained on loan from the herbarium NFC (Beltsville, MD). We thank Lic. Phil. Heino Vänskä for the Latin translations. The collecting trips were financed by the Finnish International Development Agency (FINNIDA) and the University of Helsinki.

\section{References}

Alexopoulos, C. 1953: Myxomycetes developed in moist chamber culture on bark from living Florida trees; with notes on an undescribed species of Comatricha. - Quart. J. Florida. Acad. Sci. 16:253262.

Alexopoulos, C. 1970: Rain forest Myxomycetes. In: Odum, H. (ed.), A tropical rain forest, pp. 21-23. U.S. Atomic Energy Commission.

Alexopoulos, C. \& Sáenz, R.J.A. 1975: The Myxomycetes of Costa Rica. - Mycotaxon 2:223-271.

Almeida, M.G. 1973: Contribuiçao para o conhecimento dos Myxomycetes de Angola 1. - Bol. Soc. Broteriana 47:277-297.

Almeida, M.G. 1974a: Contribuiçao para o conhecimento dos Myxomycetes de Angola 2. - Bol. Soc. Broteriana 48:205-210.

Almeida, M.G. 1974b: Contribuiçao para o conhecimento dos Myxomycetes de Mocambique. - Bol. Soc. Broteriana 48:205-210.

Bañares Baudet, A. \& Beltrán Tejera E. 1987. Adiciones a la flora micológica Canaria. V. - Actas VI. Simp. Nac. Bot. Cript.:201-211.
Bañares Baudet, A., Beltrán Tejera, E. \& Wildpret de la Torre W. 1986: Contribución al estudio micológico de los pinares de Tamadaba (Gran Canaria).II. Myxomycota, Ascomycotina y Basidiomycotina (Tremellales y Aphyllophorales). Vieraea 16:119-135.

Bañares Baudet, A., Beltrán Tejera, E., Losada Lima, A. \& León Arencibia, M.C. 1987: Contribución al estudio de la flora micológica del Monte de Aguas y Pasos (Los Silos, Tenerife).II. - Lazaroa 10:229-242.

Beltrán Tejera, E. 1975: Nota sobre los Myxomycetes presentes en el Archipiélago Canario. - Vieraea 6:17-24.

Beltrán Tejera, E., Bañares Baudet, A., León Arencibia M.C. \& Losada Lima A. - 1987: Contribución al estudio de la flora micológica del Monte de Aguas y Pasos (Los Silos Tenerife). I. - Actas VI. Simp. Nac. Bot. Cript.:213-224.

Beltrán Tejera, E., Bañares Baudet, A., RodríguezArmas, L., Losada Lima, A. \& León Arencibia, M.C. 1989: Contribución al estudio de la flora micológica del Monte Aguas y Pasos (Los Silos, Tenerife). III. - Docum. mycol. 76:41-58.

Bresadola, J. \& Saccardo. P.A. 1899: Fungi Congoenses. - Bull.Soc. Roy. Belgique 38:152-169.

Buyck, B. \& Rammeloo, J. 1983: Diderma (Physarales, Myxomycetes), Echinosteliales et Stemonitales (Myxomycetes). - Flore illustrée des champignons d'Afrique Centrale 11:201-244, pls. 36-43.

Champion, C.L. \& Beltrán Tejera, E. 1980: Catálogo preliminar de los Myxomycetes de Canarias. Vieraea 9:153-182.

Champion, C.L. \& Mitchell, D.W. 1980: Some Myxomycetes collected in Hong Kong. - Bull. British Mycol. Soc. 14:135-137.

Dixon, P.A. 1959: Myxomycetes of Ghana I. Stemonitis and Comatricha. - J. W. Afr. Sci. Ass. 5:101-104.

Doidge, E.M. 1950: The South African fungi and lichens to the end of 1945. - Bothalia 5:1-1094.

Duthie, A.V. 1917a: South African Myxomycetes. - S. African J. Sci. 14:456-460.

Duthie, A.V. 1917b: African Myxomycetes. - Trans. Roy. Soc. S. Africa 6:297-310.

Eichelbaum, F. 1906: Beiträge zur Kenntnis der Pilzflora des Ostusambaragebirges. Verh. Naturwiss. Ver. Hamburg 3.(14):31-34.

Ejale, A. \& Gill, L. 1991: Identifications of Myxomycetes (Order Liceales) from Bendel State, NigeriaII. - Korean J. Mycol. 4:250-252.

Ejale, A. \& Gill, L. 1992: Two new species of Myxomycetes from Southern Nigeria. - Acta Mycol. 27:267-269.

Ejale, A. \& Gill, L. 1995: Myxomycetes of Nigeria (Genera: Schenella Macbr. and Comatricha Preuss). - Mycol. Helvetica 7:105-110.

Eliasson, U. H. 1991: The myxomycete biota of the Hawaiian Islands. - Mycol. Res. 95:257-267.

Emoto, Y. 1977: The Myxomycetes of Japan. - 266 pp. Sanguo Tosho, Tokyo.

Farquharson, C. \& Lister G. 1916: Notes on South Nigerian Mycetozoa. - J. Bot. (London) 54:121-133.

Farr, M.L. 1959: O.F. Cook's Myxomycete collection from Liberia and the Canary Islands. - Lloydia 22: 295-301. 
Farr, M.L. 1969: Bredin-Archibold-Smithsonian Biological Survey of Dominica. Myxomycetes from Dominica. - Contr. United States Nat. Herb. 37:397439.

Farr, M.L. 1976: Myxomycetes. - Flora Neotropica Monogr. 16:1-304.

Farr, M.L. 1981: How to know the true slime molds. 132 pp. Wm. Brown, Dubuque, Iowa.

Faurel, L., Feldmann, J. \& Schotter, G. 1965: Catalogue des Myxomycètes de l'Afrique du Nord. Bull. Soc. Hist. Nat. Africa N.S. 55:7-35.

Faurel, L. \& Schotter, G. 1965: Notes Mycologiques 6. Sur quelques champignons coprophiles d'Afrique Equatoriale. - Cah. Maboké 3:123-132.

Gilbert, H.C. \& Martin, G.W. 1933: Myxomycetes found on the bark of living trees. - Univ. Iowa Stud. Nat. Hist. 15:3-8.

Gilert, E. 1990: On the identity of Perichaena liceoides (Myxomycetes). - Mycol. Res. 94:698-704.

Gill, L.S. \& Onyibe, H.I. 1986: Phytosociological studies of epiphytic flora of oil palm (Elaieis guineensis Jacq.) in Benin City, Nigeria. - Feddes Repert. 97:691-695.

González Luis, M. \& Beltrán Tejera, E. 1987: Contribución al estudio micológico del Monte de Agua García y Cerro del Lomo. Tenerife. - Vieraea 17:369-391.

Gottsberger, G. 1968: Myxomyceten aus Bahia und Goias. - Nova Hedwigia 15:361-370.

Gràcia, E. 1986: Tres Mixomicetes de la Costa d'Ivori. - Fol. Bot. Misc. 5:141-147.

Gray, D., Alexopoulos, C. 1968: Biology of the Myxomycetes. -228 pp. Ronald Press, New York.

Hagelstein, R. 1944: The Mycetozoa of North America. - 306 pp. Privately published, Mineola, New York.

Härkönen, M. 1979: Ecological, taxonomical and chorological studies on Finnish Myxomycetes. $\mathrm{PhD}$ thesis. - Publ. Dept. Bot. Univ. Helsinki N:o 5.

Härkönen, M. 1981: Gambian Myxomycetes developed in moist chamber cultures. - Karstenia 23:1-9.

Härkönen, M. 1987: Some additions to the knowledge of Turkish Myxomycetes. - Karstenia 27:1-7.

Härkönen, M., Buyck, B., Saarimäki, T. \& Mwasumbi, L. 1993: Tanzanian mushrooms and their uses 1. Russula. - Karstenia 33:11-50.

Härkönen, M. \& Saarimäki, T. 1991: Tanzanian Myxomycetes: first survey. - Karstenia 31: 41-54.

Härkönen, M \& Uotila, P. 1983: Turkish Myxomycetes developed in moist chamber cultures. - Karstenia 23:1-9.

Ing, B. 1964: Myxomycetes from Nigeria. - Trans. British Mycol. Soc. 47:49-55.

Ing, B. 1967: Myxomycetes from Sierra Leone. - Trans. British Mycol. Soc. 50:549-553.

Ing, B. 1982: Notes on Myxomycetes 3. - Trans. British Mycol. Soc. 78:439-446.

Ing, B. \& McHugh, R. 1968: Myxomycetes from Nigeria 2. - Trans. British Mycol. Soc. 51:215-220.

Keller, H.W. \& Brooks, T.E. 1976: Corticolous Myxomycetes 4: Badhamiopsis, a new genus for Badhamia ainoae. - Mycologia 68:834-841.

Keller, H.W. \& Brooks, T.E. 1977: Corticolous Myxomycetes 7: Contribution toward a monograph of Licea, five new species. - Mycologia 69:667-684.
Keller, H.W., Eliasson, U.H., Braun, K.L. \& BubenZurey, M.J. 1988: Corticolous Myxomycetes 10: Ultrastructure and taxonomic status of Cribraria minutissima and C. confusa. - Mycologia. 80:536545.

Koponen, T., Niemelä, T., Härkönen, M. \& Koponen, A. 1990: Vegetation and ecology of the Tanzanian montane and rain forest. -145 pp. Final report of FINNIDA. Project no. 282097 01-1.

Lister, A. 1925: A monograph of the Mycetozoa. 3rd ed., revised by G. Lister. - 296 pp., 222 pls. Witherby, London.

Maimoni-Rodella, R.S. \& Gottsberger, G. 1980: Myxomycetes from the forest and the cerrado vegetation in Botucatu, Brazil. A comparative ecological study. - Nowa Hedwigia 34:207-245.

Maire, R. \& Patouillard, N. \& Pinoy, E. 1926: Myxomycètes de 1'Afrique du Nord. - Bull. Soc. Hist. Nat. Afr. Nord 17:38-43.

Malençon, G. \& Bertault, R. 1967: Champignons du Maroc. - Bull. Soc. Sci. Nat. Phys. Maroc 47:237-281.

Martin, G. \& Alexopoulos, C. 1969: The Myxomycetes. - 560 pp. Univ. Iowa Press, Iowa City.

Mitchell, D.W. 1980: A key to the corticolous Myxomycetes. - 63 pp. Brit. Mycol. Soc., Cambridge.

Mitchell, D.W. \& Kylin, H. 1984: Some Tunisian Myxomycetes. - Bull. British Mycol. Soc. 18:64-65.

Nannenga-Bremekamp, N.E. 1971: Notes on Myxomycetes 17. Some new species in Cribraria, Comatricha and Physarum, a new variety in Macbrideola and a new name in Arcyria. - Proc. Kon. Nederlandse Akad. Wetensch. C 74:352-365.

Nannenga-Bremekamp, N.E. 1991: A guide to temperate Myxomycetes. - 409 pp. Biopress, Bristol. (Engl. transl. by A. Feest and Y. Burggraaf of De Nederlandse Myxomyceten. - 460 pp. Kon. Nederl. Nat. Ver., Zutphen.)

Nannenga-Bremekamp, N.E. \& Yamamoto Y. 1983: Additions to the Myxomycetes of Japan 1.- Proc. Kon. Nederlandse Akad. Wetensch. C 86:207-241.

Nannenga-Bremekamp, N.E. \& Yamamoto, Y. 1987: Additions to the Myxomycetes of Japan 3. - Proc. Kon. Nederlandse Akad. Wetensch. C 90:311-349.

Nannenga-Bremekamp, N.E. \& Yamamoto, Y. 1990: Additions to the Myxomycetes of Japan 4 - Proc. Kon. Nederlandse Akad. Wettensch. 93: 265-280.

Neubert, H. \& Nannenga-Bremekamp, N.E. 1979: Revision des Myxomyceten Arcyria minuta Buchet. Z. Mykol. 45:239-245.

Neubert, H., Nowotny, W. \& Bauman, K. 1993: Die Myxomyceten Deutschlands und des angrenzenden Alpenraumes unter besonderer Berücksichtigung Österreichs 1. Ceratiomyxales, Echinosteliales, Licheales, Trichiales. - 343 pp. Karlheinz Bauman Verlag, Gomaringen.

Niemelä, T. 1988: Itä-Afrikan vuoristojen metsät ja sademetsät. Summary: East African montane forest and rain forest. In: Erkkilä, J. \& Kuuluvainen, T. (eds.), Tropiikin metsät. - Silva Carelica 12:57-72.

Patouillard. N. 1897: Additions au catalogue des champignons de la Tunisie. - Bull. Soc. Mycol. France 13:197-216.

Patouillard, N. 1928: Contribution à l'étude des Champignons de Madagascar. - Mem. Acad. Malgache 6:1-49. 
Polhill, D. 1988: Flora of East Tropical Africa. Index of collecting localities. - 398 pp. Royal Bot. Gardens, Kew.

Rammeloo, J. 1973a: Contribution à la connaissance des Myxomycètetes du Maroc (1 re note). - Bull. Soc. Sci. Nat. Phys. Maroc 53:31-35.

Rammeloo, J. 1973b: Trichia arundinariae, sp. nov. (Myxomycetes, Trichiales) from the National Kahuzi Park (Zaire). - Bull. Nat. Plantentuin België 43:349352.

Rammeloo, J. 1981a: Trichiales (Myxomycetes). - Flore illustrée des champignons d'Afrique centrale 89:135-169, pls. 23-31.

Rammeloo, J. 1981b: Five new Myxomycete species (Trichiales) from Rwanda. - Bull. Nat. Plantentuin België 51:229-230.

Rammeloo. J. \& Mitchell, D. 1994: Contribucation towards the knowledge of Myxomycetes of Malawi and Zambia. - J.H. Seyani \& A.C. Chikuni, Proc. XIII Plenary Meeting AETFAT, Malawi, 1:785-793.
Reynolds, D. \& Alexopoulos, C. 1971: Southeast Asian Myxomycetes 1. Thailand and Burma. - Pacific Science 25:33-38.

Stephenson, S.L. 1989: Distribution and ecology of Myxomycetes in temperate forests 2. Patterns of occurrence on bark surface of living trees, leaf litter, and dung. - Mycologia 8:608-621.

Stephenson. S.L., \& Stempen H. 1994: Myxomycetes: a handbook of slime molds. - 183 pp. Timber Press, Portland, Oregon.

Ukkola, T. \& Härkönen M. 1996: Revision of Physarum pezizoideum var. pezizoideum and var. microsporum (Myxomycetes). - Karstenia 36:41-46.

Wildpret, W. \& Beltrán, E. 1974: Contribución al estudio de la flora micológica del Archipiélago Canario. - Anal. Inst. Bot. Cavanilles 31:5-18.

Yamamoto, Y., Hagiwara, H. \& Sultana, K. 1993: Myxomycetes from northern Pakistan 2. - Cryptog. Fl. Pakistan 2:25-41.

Received on 6 November 1995 